\title{
Biodiversity of Yeasts in the Gastrointestinal Ecosystem with Emphasis on Its Importance for the Host
}

\author{
Vladimir Urubschurov and Pawel Janczyk \\ Chair for Nutrition Physiology and Animal Nutrition, University of Rostock
}

Germany

\section{Introduction}

Thinking of the diversity of the microbial world most readers will focus their attention to the bacteria and archea. However, among most of the ecosystems present on Earth, such as soil or intestine of animals, another microbial group has established: the yeasts. Their biodiversity has been hardly investigated although they possess probably as much adaptation potential as bacteria, considering the enormous differences between the habitats and the challenges the different ecosystems must face.

In the chapter the authors would like to provide to the reader the state of the art in the field of intestinal yeast research, with focus on the diversity of the yeasts in the gastrointestinal tract of animals - insects and mammals. Up to date there are about 1,500 yeast species known, belonging to two phyla Ascomycota (Suh et al., 2006a) and Basidiomycota (Fell et al., 2000; Scorzetti et al., 2002) of the Dikarya subkingdom (Kurtzman \& Fell, 2006). These unicellular fungi are considered as ubiquitous microorganisms, which can be found in a vast variety of different ecological systems associated with terrestrial and underwater flora and fauna (Rosa $\&$ Peter, 2006). Nevertheless, based on the currently researches it could be suggested that only $1 \%$ of the diversity of yeast species has been described yet (Kurtzman \& Fell, 2006).

The gastrointestinal tract (GIT) of animals remains a largely unexplored habitat. Most of the yeasts were isolated from the GIT of beetles and other insects. The current knowledge about yeasts' diversity in the digestive tract of vertebrates, especially of farm animals, is still based generally on the findings from 50's and 70's of the XXth Century. Furthermore, the taxonomy of yeasts undergoes continuous revision, e.g., variety of yeasts has double names or even many synonyms. This came off due to the fact that sometimes the same yeasts have been described by different scientists (Kurtzman \& Fell, 1998) or several yeasts were invalidly classified, e.g., species assigned to genus Torulopsis were reclassified to the genus Candida (Yarrow \& Meyer, 1978). Moreover, it transpires frequently when yeast species previously described based on its phenotypic characteristics has been later phylogenetically analysed and on that basis reclassified into another genus, consequently obtained a new name (Kurtzman \& Fell, 2006). Therefore, few yeast species will be mentioned in the further sections with a double name.

Furthermore, in this review we will provide some consideration to the importance of the yeasts for the host. Advantages and disadvantages of the contemporary methods used for diversity studies will also be pointed. 


\section{Biodiversity of yeasts in the gastrointestinal ecosystem}

Microorganisms live in the diverse habitats of the world. In course of evolution, some microbes adapted to the extreme environment prevailing in the gastrointestinal ecosystem of human and animals. Gastrointestinal tracts of mammals (Hooper \& Gordon, 2001; Bauer et al., 2006; Ley et al., 2008) and insects (Dillon \& Dillon, 2004; Hongoh, 2010; Grunwald et al., 2010) harbour vast bacterial communities which undoubtedly play an important role for the maturation and proper function of mucosal and systemic immune systems, nutrient metabolism and host health. In contrast, the knowledge of yeasts which naturally occur in intestine and thereby belong to the intestinal microbiota still remains deficient.

\subsection{Yeasts' diversity in the alimentary tract of insects}

Insects are among the most diverse group of animals that has been found worldwide (Chapman, 2009) and they unavoidably come into contact with yeasts widespread in various habitats like soil (Botha, 2006), plants (Fonseca \& Inàcio, 2006) and fresh and marine water (Nagahama, 2006). This has been confirmed by the fact that yeasts can be found on body surface as well as in the entrails of insects: beetles, bees, flies, lacewings, termites, and mosquitoes; and their larvae. Table 1 summarises the yeast species that were recently discovered in the GIT of insects and that have particularly been identified using molecular methods.

\subsubsection{Yeasts associated with flowers and gut of bees}

In general, insects can be considered as either as a vector carrying yeasts on the body surface or the consumers of the yeasts (for review see Phaff \& Starmer, 1987; Ganter, 2006). For instance, since yeasts regularly occur in flowers they are considered as autochthonous for this environment, and so they are closely associated with flower-visiting insects (Lachance et al., 2001; Brysch-Herzberg, 2004). In floristic nectar, ascomycetous yeasts belonging to the genera Metschnikowia, Kodamaea, Wickerhamiella have been found in higher abundance, whereas basidiomycetous yeasts (e.g. Cryptococcus spp., Rhodotorula spp., Pseudozyma spp.) were rarely isolated (Lachance et al., 2001; Brysch-Herzberg, 2004). Brysch-Herzberg (2004) counted an astonishing number of yeast cells (up to 16,000 cells $/ \mu 1$ nectar) from the nectar samples of Digitalis purpurea. In this study, yeasts were isolated from nectar, plant materials, honey and from body of bumblebees, but unfortunately not from the GIT. In another study (Batra et al., 1973), the same yeasts (species of Candida, Endomycopsis, Oidium, Hansenula, Rhodotorula, Saccharomyces, Schizosaccharomyces, Pichia, and Zygosaccharomyces) were found in nectar and in the crops of bees, however, in the last niche yeasts were determined to be in higher, about 10 to 100 fold, concentration. Gilliam et al. (1974) summarized the data of yeasts isolated from the digestive tract of honey bees and also reported about their own investigations on yeasts in intestines of 388 adult worker honey bees.

Seven species were observed in the study, but three: Candida (Torulopsis) magnoliae, Candida parapsilosis, and Candida (Torulopsis) glabrata were found most frequently providing evidence for their dominance in this environment.

\subsubsection{Yeasts associated with digestive tract of ants and termites}

Ants, belonging like bees to the order Hymenoptera, have been also associated closely with variety of yeasts harbouring their nests (Carreiro et al., 1997; Rodrigues et al., 2009; Pagnocca et al., 2010). Some yeasts can pass into the infrabuccal pocket, a pouch in the ants' 


\begin{tabular}{|c|c|c|}
\hline Species & Host organism & References \\
\hline Ambrosiozyma monospora & owlfly (Ascalaphidae) & (Nguyen et al., 2007) \\
\hline Aureobasidium pullulans & leaf beetles (Chrysomelidae) & (Molnar et al., 2008) \\
\hline $\begin{array}{l}\text { Candida aglyptinia } \\
\text { sp. nov. }\end{array}$ & round fungus beetle (Leiodidae) & (Suh et al., 2006b) \\
\hline $\begin{array}{l}\text { Candida alai } \\
\text { sp. nov. }\end{array}$ & click beetle (Elateridae) & (Suh et al., 2008) \\
\hline Candida ambrosiae & $\begin{array}{l}\text { pleasing fungus beetle (Erotylidae); } \\
\text { darkling beetle (Tenebrionidae); sap- } \\
\text { feeding beetle (Nitidulidae) }\end{array}$ & (Suh et al., 2004b) \\
\hline $\begin{array}{l}\text { Candida amphixiae } \\
\text { sp. nov. }\end{array}$ & $\begin{array}{l}\text { handsome fungus beetle } \\
\text { (Endomychidae) }\end{array}$ & (Suh et al., 2005b) \\
\hline $\begin{array}{l}\text { Candida anneliseae } \\
\text { sp. nov. }\end{array}$ & $\begin{array}{l}\text { pleasing fungus beetles (Erotylidae); } \\
\text { darkling beetles (Tenebrionidae); rove } \\
\text { beetle (Staphylinidae); false darkling } \\
\text { beetles (Melandryidae); clown beetle } \\
\text { (Histeridae); minute tree-fungus } \\
\text { beetle (Ciidae) }\end{array}$ & (Suh et al., 2004b) \\
\hline Candida arabinofermentans & bark beetles (Scolytinae) & (Rivera et al., 2009) \\
\hline $\begin{array}{l}\text { Candida ascalaphidarum } \\
\text { sp. nov. }\end{array}$ & $\begin{array}{l}\text { owlfly (Ascalaphidae); largus bug } \\
\text { (Largidae); fungus weevil } \\
\text { (Anthribidae) }\end{array}$ & (Nguyen et al., 2007) \\
\hline $\begin{array}{l}\text { Candida atakaporum } \\
\text { sp. nov. }\end{array}$ & pleasing fungus beetle (Erotylidae) & (Suh et al., 2004b) \\
\hline $\begin{array}{l}\text { Candida atbi } \\
\text { sp. nov. }\end{array}$ & sap-feeding beetles (Nitidulidae) & (Suh et al., 2006b) \\
\hline $\begin{array}{l}\text { Candida athensensis } \\
\text { sp. nov. }\end{array}$ & $\begin{array}{l}\text { beetles: cucujoid, curculionid, } \\
\text { Megalodacne fasciata (Erotylidae) }\end{array}$ & $\begin{array}{l}\text { (Suh \& Blackwell, } \\
\text { 2004) }\end{array}$ \\
\hline $\begin{array}{l}\text { Candida barrocoloradensis } \\
\text { sp. nov. }\end{array}$ & sap-feeding beetles (Nitidulidae) & (Suh et al., 2006b) \\
\hline $\begin{array}{l}\text { Candida blattae } \\
\text { sp. nov. }\end{array}$ & $\begin{array}{l}\text { cockroach (Blattidae); dobsonfliy } \\
\text { (Corydalidae) }\end{array}$ & (Nguyen et al., 2007) \\
\hline $\begin{array}{l}\text { Candida blattariae } \\
\text { sp. nov. }\end{array}$ & cockroach (Blattaria) & (Suh et al., 2005b) \\
\hline $\begin{array}{l}\text { Candida bohiensis } \\
\text { sp. nov. }\end{array}$ & $\begin{array}{l}\text { click beetles (Elateridae); leaf beetle } \\
\text { (Chrysomelidae) }\end{array}$ & (Suh et al., 2008) \\
\hline $\begin{array}{l}\text { Candida bokatorum } \\
\text { sp. nov. }\end{array}$ & $\begin{array}{l}\text { pleasing fungus beetles (Erotylidae); } \\
\text { ground beetle (Carabidae); sap-feeding } \\
\text { beetle (Nitidulidae); false darkling } \\
\text { beetle (Melandryidae); darkling beetle } \\
\text { (Tenebrionidae) }\end{array}$ & (Suh et al., 2004b) \\
\hline $\begin{array}{l}\text { Candida bolitotheri } \\
\text { sp. nov. }\end{array}$ & $\begin{array}{l}\text { darkling beetles (Tenebrionidae); } \\
\text { pleasing fungus beetle (Erotylidae) }\end{array}$ & (Suh et al., 2004b) \\
\hline
\end{tabular}




\begin{tabular}{|c|c|c|}
\hline Species & Host organism & References \\
\hline $\begin{array}{l}\text { Candida bribrorum } \\
\text { sp. nov. }\end{array}$ & $\begin{array}{l}\text { pleasing fungus beetles (Erotylidae); } \\
\text { darkling beetles (Tenebrionidae) }\end{array}$ & (Suh et al., 2004b) \\
\hline $\begin{array}{l}\text { Candida buenavistaensis } \\
\text { sp. nov. }\end{array}$ & $\begin{array}{l}\text { longhorned beetle (Cerambycidae); } \\
\text { scarab beetle (Scarabaeidae) }\end{array}$ & (Suh et al., 2008) \\
\hline Candida cf neerlandica & $\begin{array}{l}\text { owlfllies (Ascalaphidae); earwig } \\
\text { (Labiduridae); cricket (Gryllidae) }\end{array}$ & $\begin{array}{l}\text { (Nguyen et al., 2007; } \\
\text { Suh et al., 2008) }\end{array}$ \\
\hline $\begin{array}{l}\text { Candida chickasaworum } \\
\text { sp. nov. }\end{array}$ & $\begin{array}{l}\text { pleasing fungus beetles (Erotylidae); } \\
\text { minute tree-fungus beetle (Ciidae) }\end{array}$ & (Suh et al., 2004b) \\
\hline $\begin{array}{l}\text { Candida choctaworum } \\
\text { sp. nov. }\end{array}$ & $\begin{array}{l}\text { darkling beetles (Tenebrionidae); } \\
\text { minute tree-fungus beetles (Ciidae); } \\
\text { fungus weevil (Anthribidae) }\end{array}$ & (Suh et al., 2004b) \\
\hline $\begin{array}{l}\text { Candida chrysomelidarum } \\
\text { sp. nov. }\end{array}$ & leaf beetles (Chrysomelidae) & (Nguyen et al., 2006) \\
\hline $\begin{array}{l}\text { Candida corydali } \\
\text { sp. nov. }\end{array}$ & dobsonflies and fishflies (Corydalidae) & (Nguyen et al., 2007) \\
\hline $\begin{array}{l}\text { Candida derodonti } \\
\text { sp. nov. }\end{array}$ & $\begin{array}{l}\text { tooth-necked fungus beetles } \\
\text { (Derodontidae) }\end{array}$ & $\begin{array}{l}\text { (Suh \& Blackwell, } \\
\text { 2005) }\end{array}$ \\
\hline $\begin{array}{l}\text { Candida dosseyi } \\
\text { sp. nov. }\end{array}$ & dobsonflies (Corydalidae) & (Nguyen et al., 2007) \\
\hline $\begin{array}{l}\text { Candida elateridarum } \\
\text { sp. nov. }\end{array}$ & click beetle (Elateridae) & $\begin{array}{l}\text { (Suh \& Blackwell, } \\
\text { 2004) }\end{array}$ \\
\hline $\begin{array}{l}\text { Candida emberorum } \\
\text { sp. nov. }\end{array}$ & $\begin{array}{l}\text { pleasing fungus beetles (Erotylidae); } \\
\text { handsome fungus beetle } \\
\text { (Endomychidae) }\end{array}$ & (Suh et al., 2004b) \\
\hline $\begin{array}{l}\text { Candida endomychidarum } \\
\text { sp. nov. }\end{array}$ & $\begin{array}{l}\text { handsome fungus beetle } \\
\text { (Endomychidae) }\end{array}$ & (Suh et al., 2005b) \\
\hline Candida ernobii & bark beetles (Scolytinae) & (Rivera et al., 2009) \\
\hline \multirow[t]{3}{*}{ Candida fermentati } & $\begin{array}{l}\text { sap-feeding beetle (Nitidulidae); } \\
\text { scarab beetle (Scarabaeidae) }\end{array}$ & $\begin{array}{l}\text { (Suh \& Blackwell, } \\
\text { 2004) }\end{array}$ \\
\hline & fishfly (Corydalidae) & (Nguyen et al., 2007) \\
\hline & mosquitoes (Culicidae) & (Gusmão et al., 2010) \\
\hline $\begin{array}{l}\text { Candida frijolesensis } \\
\text { sp. nov. }\end{array}$ & $\begin{array}{l}\text { handsome fungus beetle } \\
\text { (Endomychidae); elephant beetle } \\
\text { (Scarabaeidae) }\end{array}$ & (Suh et al., 2008) \\
\hline $\begin{array}{l}\text { Candida gatunensis } \\
\text { sp. nov. }\end{array}$ & sap-feeding beetles (Nitidulidae) & (Suh et al., 2006b) \\
\hline $\begin{array}{l}\text { Candida gigantensis } \\
\text { sp. nov. }\end{array}$ & click beetles (Elateridae) & (Suh et al., 2008) \\
\hline $\begin{array}{l}\text { Candida guaymorum } \\
\text { sp. nov. }\end{array}$ & $\begin{array}{l}\text { pleasing fungus beetles (Erotylidae); } \\
\text { scarab beetle (Scarabaeidae) }\end{array}$ & (Suh et al., 2004b) \\
\hline Candida intermedia & mosquitoes (Culicidae) & (Ricci et al., 2011a) \\
\hline
\end{tabular}




\begin{tabular}{|c|c|c|}
\hline Species & Host organism & References \\
\hline Candida kruisii & sap-feeding beetles (Nitidulidae) & (Suh et al., 2006b) \\
\hline $\begin{array}{l}\text { Candida kunorum } \\
\text { sp. nov. }\end{array}$ & sap-feeding beetle (Nitidulidae) & (Suh et al., 2004b) \\
\hline $\begin{array}{l}\text { Candida labiduridarum } \\
\text { sp. nov. }\end{array}$ & $\begin{array}{l}\text { earwig (Labiduridae); cricket } \\
\text { (Gryllidae); owlflies (Ascalaphidae) }\end{array}$ & (Suh et al., 2008) \\
\hline \multirow[t]{2}{*}{$\begin{array}{l}\text { Candida lessepsii } \\
\text { sp. nov. }\end{array}$} & unidentified beetle & (Suh et al., 2005b) \\
\hline & bark beetles (Scolytinae) & (Rivera et al., 2009) \\
\hline $\begin{array}{l}\text { Candida lycoperdinae } \\
\text { sp. nov. }\end{array}$ & $\begin{array}{l}\text { sap-feeding beetle (Nitidulidae); } \\
\text { scarab beetle (Scarabaeidae) }\end{array}$ & (Suh et al., 2006b) \\
\hline Candida maltosa & $\begin{array}{l}\text { click beetles (Elateridae); bess beetles } \\
\text { (Passalidae); scarab beetle } \\
\text { (Scarabaeidae) }\end{array}$ & (Suh et al., 2008) \\
\hline $\begin{array}{l}\text { Candida maxii } \\
\text { sp. nov. }\end{array}$ & darkling beetle (Tenebrionidae) & (Suh et al., 2004b) \\
\hline Candida membranifaciens & $\begin{array}{l}\text { cranefly (Tipulidae); dobsonfly } \\
\text { (Corydalidae); green lacewings } \\
\text { (Chrysopidae) }\end{array}$ & $\begin{array}{l}\text { (Suh et al., 2005b; } \\
\text { Nguyen et al., 2007) }\end{array}$ \\
\hline $\begin{array}{l}\text { Candida michaelii } \\
\text { sp. nov. }\end{array}$ & $\begin{array}{l}\text { handsome fungus beetle } \\
\text { (Endomychidae) }\end{array}$ & (Suh et al., 2005b) \\
\hline Candida nodaensis & mosquitoes (Culicidae) & (Gusmão et al., 2010) \\
\hline Candida oregonensis & bark beetles (Scolytinae) & (Rivera et al., 2009) \\
\hline $\begin{array}{l}\text { Candida pallodes } \\
\text { sp. nov. }\end{array}$ & sap-feeding beetles (Nitidulidae) & (Suh et al., 2006b) \\
\hline $\begin{array}{l}\text { Candida panamensis } \\
\text { sp. nov. }\end{array}$ & $\begin{array}{l}\text { sap-feeding beetles (Nitidulidae); } \\
\text { darkling beetle (Tenebrionidae) }\end{array}$ & (Suh et al., 2006b) \\
\hline $\begin{array}{l}\text { Candida panamericana } \\
\text { sp. nov. }\end{array}$ & $\begin{array}{l}\text { pleasing fungus beetle (Erotylidae); } \\
\text { rove beetle (Staphylinidae); darkling } \\
\text { beetle (Tenebrionidae) }\end{array}$ & (Suh et al., 2004b) \\
\hline \multirow[t]{2}{*}{$\begin{array}{l}\text { Candida picachoensis } \\
\text { sp. nov. }\end{array}$} & green lacewings (Chrysopidae) & (Suh et al., 2004a) \\
\hline & leaf beetles (Chrysomelidae) & (Nguyen et al., 2006) \\
\hline Candida piceae & bark beetles (Scolytinae) & (Rivera et al., 2009) \\
\hline \multirow[t]{2}{*}{$\begin{array}{l}\text { Candida pimensis } \\
\text { sp. nov. }\end{array}$} & green lacewings (Chrysopidae) & (Suh et al., 2004a) \\
\hline & & (Nguyen et al., 2006) \\
\hline $\begin{array}{l}\text { Candida plutei } \\
\text { sp. nov. }\end{array}$ & rove beetle (Staphylinidae) & $\begin{array}{l}\text { (Suh \& Blackwell, } \\
\text { 2005) }\end{array}$ \\
\hline Candida pseudorhagii & click beetle (Elateridae) & (Suh et al., 2008) \\
\hline \multirow[t]{2}{*}{ Candida quercitrusa } & dobsonfly (Corydalidae) & (Nguyen et al., 2007) \\
\hline & cotton bollworm (Noctuidae) & (Molnar et al., 2008) \\
\hline
\end{tabular}




\begin{tabular}{|c|c|c|}
\hline Species & Host organism & References \\
\hline Candida sake & $\begin{array}{l}\text { crambid snout moths (Crambidae); } \\
\text { cotton bollworm (Noctuidae) }\end{array}$ & (Molnar et al., 2008) \\
\hline Candida sinolaborantium & $\begin{array}{l}\text { handsome fungus beetle } \\
\text { (Endomychidae); cerambycid larvae } \\
\text { (Cerambycidae) }\end{array}$ & (Suh et al., 2005b) \\
\hline $\begin{array}{l}\text { Candida smithsonii } \\
\text { sp. nov. }\end{array}$ & $\begin{array}{l}\text { endomychid larva (Endomychidae); } \\
\text { Iphiclus beetle (Erotylidae) }\end{array}$ & $\begin{array}{l}\text { (Suh \& Blackwell, } \\
\text { 2004) }\end{array}$ \\
\hline $\begin{array}{l}\text { Candida stri } \\
\text { sp. nov. }\end{array}$ & sap-feeding beetles (Nitidulidae) & (Suh et al., 2006b) \\
\hline $\begin{array}{l}\text { Candida taliae } \\
\text { sp. nov. }\end{array}$ & darkling beetle (Tenebrionidae) & (Suh et al., 2004b) \\
\hline $\begin{array}{l}\text { Candida temnochilae } \\
\text { sp. nov. }\end{array}$ & $\begin{array}{l}\text { bark-gnawing beetle (Trogossitidae); } \\
\text { bess beetle (Passalidae) }\end{array}$ & (Suh et al., 2005b) \\
\hline Candida tenuis & minute tree-fungus beetle (Ciidae) & (Suh et al., 2005b) \\
\hline $\begin{array}{l}\text { Candida terraborum } \\
\text { sp. nov. }\end{array}$ & pleasing fungus beetle (Erotylidae) & (Suh et al., 2004b) \\
\hline $\begin{array}{l}\text { Candida tetrigidarum } \\
\text { sp. nov. }\end{array}$ & $\begin{array}{l}\text { elephant beetle (Scarabaeidae); pygmy } \\
\text { grasshopper (Tetrigidae) }\end{array}$ & (Suh et al., 2008) \\
\hline $\begin{array}{l}\text { Candida tritomae } \\
\text { sp. nov. }\end{array}$ & $\begin{array}{l}\text { pleasing fungus beetles (Erotylidae); } \\
\text { scarab beetle (Scarabaeidae) }\end{array}$ & (Suh et al., 2006b) \\
\hline Candida tropicalis & $\begin{array}{l}\text { owlfly (Ascalaphidae); bess beetles } \\
\text { (Passalidae); ichneumon wasps } \\
\text { (Ichneumonidae); dobsonfly and } \\
\text { fishfly (Corydalidae); roach (Blattidae) }\end{array}$ & $\begin{array}{l}\text { (Nguyen et al., 2007; } \\
\text { Suh et al., 2008) }\end{array}$ \\
\hline $\begin{array}{l}\text { Candida wounanorum } \\
\text { sp. nov. }\end{array}$ & pleasing fungus beetle (Erotylidae) & (Suh et al., 2004b) \\
\hline Candida xestobii & $\begin{array}{l}\text { crambid snout moths (Crambidae); } \\
\text { leaf beetle (Chrysomelidae) }\end{array}$ & (Molnar et al., 2008) \\
\hline $\begin{array}{l}\text { Candida yuchorum } \\
\text { sp. nov. }\end{array}$ & pleasing fungus beetle (Erotylidae) & (Suh et al., 2004b) \\
\hline Clavispora lustansiae & blister beetle (Meloidae) & (Rao et al., 2007) \\
\hline Cryptococcus flavescens & $\begin{array}{l}\text { crambid snout moth (Crambidae); } \\
\text { cotton bollworm (Noctuidae); leaf } \\
\text { beetles (Chrysomelidae) }\end{array}$ & (Molnar et al., 2008) \\
\hline \multirow[t]{2}{*}{ Cryptococcus luteolus } & $\begin{array}{l}\text { crambid snout moths (Crambidae); } \\
\text { leaf beetles (Chrysomelidae) }\end{array}$ & (Molnar et al., 2008) \\
\hline & green lacewings (Chrysopidae) & $\begin{array}{l}\text { (Woolfolk \& Inglis, } \\
\text { 2004) }\end{array}$ \\
\hline Cryptococcus oeirensis & leaf beetle (Chrysomelidae) & (Molnar et al., 2008) \\
\hline \multirow[t]{2}{*}{ Cryptococcus victoriae } & crambid snout moth (Crambidae) & (Molnar et al., 2008) \\
\hline & green lacewings (Chrysopidae) & $\begin{array}{l}\text { (Woolfolk \& Inglis, } \\
\text { 2004) }\end{array}$ \\
\hline
\end{tabular}




\begin{tabular}{|c|c|c|}
\hline Species & Host organism & References \\
\hline Cryptococcus zeae & $\begin{array}{l}\text { crambid snout moths (Crambidae); } \\
\text { leaf beetle (Chrysomelidae) }\end{array}$ & (Molnar et al., 2008) \\
\hline $\begin{array}{l}\text { Geotrichum carabidarum } \\
\text { sp. nov. }\end{array}$ & $\begin{array}{l}\text { ground beetle (Carabidae); geometrid } \\
\text { larva (Geometridae); pleasing fungus } \\
\text { beetle (Erotylidae) }\end{array}$ & $\begin{array}{l}\text { (Suh \& Blackwell, } \\
\text { 2006) }\end{array}$ \\
\hline $\begin{array}{l}\text { Geotrichum cucujoidarum } \\
\text { sp. nov. }\end{array}$ & $\begin{array}{l}\text { minute tree-fungus beetle (Ciidae); } \\
\text { cucujoid beetle (Cucujoidae); hining } \\
\text { fungus beetle (Scaphidiinae) }\end{array}$ & $\begin{array}{l}\text { (Suh \& Blackwell, } \\
\text { 2006) }\end{array}$ \\
\hline $\begin{array}{l}\text { Geotrichum histeridarum } \\
\text { sp. nov. }\end{array}$ & $\begin{array}{l}\text { clown beetles (Histeridae); pleasing } \\
\text { fungus beetle (Erotylidae); geometrid } \\
\text { larvae (Geometridae); tiger moths } \\
\text { (Arctiidae) }\end{array}$ & $\begin{array}{l}\text { (Suh \& Blackwell, } \\
\text { 2006) }\end{array}$ \\
\hline \multirow[t]{2}{*}{ Hanseniaspora uvarum } & crambid snout moths (Crambidae) & (Molnar et al., 2008) \\
\hline & mosquitoes (Culicidae) & (Ricci et al., 2011a) \\
\hline Hanseniaspora vineae & dobsonflies and fishflies (Corydalidae) & (Nguyen et al., 2007) \\
\hline Issatchenkia orientalis & scarab beetle (Scarabaeidae) & (Rao et al., 2007) \\
\hline $\begin{array}{l}\text { Kodamaea laetipori } \\
\text { sp. nov. }\end{array}$ & $\begin{array}{l}\text { darkling beetles (Tenebrionidae); } \\
\text { scarab beetles (Scarabaeidae) }\end{array}$ & $\begin{array}{l}\text { (Suh \& Blackwell, } \\
\text { 2005) }\end{array}$ \\
\hline \multirow[t]{2}{*}{ Kodamaea ohmeri } & $\begin{array}{l}\text { dobsonfly (Corydalidae); sap-feeding } \\
\text { beetle (Nitidulidae); pleasing fungus } \\
\text { beetle (Erotylidae) }\end{array}$ & $\begin{array}{l}\text { (Suh \& Blackwell, } \\
\text { 2005; Nguyen et al., } \\
\text { 2007) }\end{array}$ \\
\hline & mosquitoes (Culicidae) & (Gusmão et al., 2010) \\
\hline Kuraishia capsulata & bark beetles (Scolytinae) & (Rivera et al., 2009) \\
\hline Kuraishia cf. molischiana & bark beetles (Scolytinae) & (Rivera et al., 2009) \\
\hline Lachancea fermentati & dobsonflies and fishflies (Corydalidae) & (Nguyen et al., 2007) \\
\hline Lachancea thermotolerans & dobsonflies and fishflies (Corydalidae) & (Nguyen et al., 2007) \\
\hline Lodderomyces elongisporus & bark and ambrosia beetle (Scolytinae) & (Suh et al., 2008) \\
\hline $\begin{array}{l}\text { Metschnikowia andauensis } \\
\text { sp. nov. }\end{array}$ & cotton bollworm (Noctuidae) & $\begin{array}{l}\text { (Molnar \& Prillinger, } \\
\text { 2005) }\end{array}$ \\
\hline \multirow[t]{2}{*}{$\begin{array}{l}\text { Metschnikowia chrysoperlae } \\
\text { sp. nov. }\end{array}$} & green lacewings (Chrysopidae) & (Suh et al., 2004a) \\
\hline & dobsonfly (Corydalidae) & (Nguyen et al., 2007) \\
\hline $\begin{array}{l}\text { Metschnikowia corniflorae } \\
\text { sp. nov. }\end{array}$ & soldier beetles (Cantharidae) & (Nguyen et al., 2006) \\
\hline Metschnikowia fructicola & $\begin{array}{l}\text { crambid snout moths (Crambidae); } \\
\text { cotton bollworms (Noctuidae) }\end{array}$ & $\begin{array}{l}\text { (Molnar \& Prillinger, } \\
\text { 2005) }\end{array}$ \\
\hline $\begin{array}{l}\text { Metschnikowia noctiluminum } \\
\text { sp. nov. }\end{array}$ & green lacewings (Chrysopidae) & (Nguyen et al., 2006) \\
\hline \multirow[t]{2}{*}{ Metschnikowia pulcherrima } & dobsonfly (Corydalidae) & (Nguyen et al., 2007) \\
\hline & green lacewings (Chrysopidae) & $\begin{array}{l}\text { (Woolfolk \& Inglis, } \\
\text { 2004) }\end{array}$ \\
\hline
\end{tabular}




\begin{tabular}{|c|c|c|}
\hline Species & Host organism & References \\
\hline Pichia americana & bark beetles (Scolytinae) & (Rivera et al., 2009) \\
\hline Pichia canadensis & bark beetles (Scolytinae) & (Rivera et al., 2009) \\
\hline \multirow[t]{2}{*}{ Pichia caribbica } & pleasing fungus beetle (Erotylinae) & (Rao et al., 2007) \\
\hline & mosquitoes (Culicidae) & (Gusmão et al., 2007) \\
\hline Pichia glucozyma & bark beetles (Scolytinae) & (Rivera et al., 2009) \\
\hline \multirow[t]{4}{*}{ Pichia guilliermondii } & $\begin{array}{l}\text { fishfly and dobsonfly (Corydalidae); } \\
\text { owlfly (Ascalaphidae) }\end{array}$ & (Nguyen et al., 2007) \\
\hline & bark beetle (Scolytinae) & (Rivera et al., 2009) \\
\hline & $\begin{array}{l}\text { crambid snout moths (Crambidae); } \\
\text { leaf beetle (Chrysomelidae) }\end{array}$ & (Molnar et al., 2008) \\
\hline & mosquitoes (Culicidae) & (Gusmão et al., 2010) \\
\hline Pichia mexicana & bark beetles (Scolytinae) & (Rivera et al., 2009) \\
\hline $\begin{array}{l}\text { Pichia nakazawae var. } \\
\text { akitaensis }\end{array}$ & $\begin{array}{l}\text { handsome fungus beetle } \\
\text { (Endomychidae) }\end{array}$ & (Suh et al., 2005b) \\
\hline Pichia scolyti & bark beetles (Scolytinae) & (Rivera et al., 2009) \\
\hline Pseudozyma apsidi & $\begin{array}{l}\text { cotton bollworms (Noctuidae); } \\
\text { leaf beetles (Chrysomelidae) }\end{array}$ & (Molnar et al., 2008) \\
\hline Pseudozyma flocculosa & cotton bollworms (Noctuidae) & (Molnar et al., 2008) \\
\hline Pseudozyma prolifica & cotton bollworms (Noctuidae) & (Molnar et al., 2008) \\
\hline Rhodotorula aurantiaca & leaf beetle (Chrysomelidae) & (Molnar et al., 2008) \\
\hline Rhodotorula glutinis & $\begin{array}{l}\text { crambid snout moths (Crambidae); } \\
\text { leaf beetle (Chrysomelidae) }\end{array}$ & (Molnar et al., 2008) \\
\hline Saccharomyces cariocanus & dobsonflies (Corydalidae) & (Nguyen et al., 2007) \\
\hline Saccharomyces cerevisiae & dobsonflies and fishflies (Corydalidae) & (Nguyen et al., 2007) \\
\hline Saccharomyces fermentans & fishfly (Corydalidae) & (Nguyen et al., 2007) \\
\hline Saprochete gigas & dobsonfly and fishfly (Corydalidae) & (Nguyen et al., 2007) \\
\hline Sporobolomyces coprosmae & leaf beetles (Chrysomelidae) & (Molnar et al., 2008) \\
\hline Tilletiopsis washingtonensis & leaf beetle (Chrysomelidae) & (Molnar et al., 2008) \\
\hline Torulaspora delbrueckii & fishfly (Corydalidae) & (Nguyen et al., 2007) \\
\hline $\begin{array}{l}\text { Trichosporon insectorum } \\
\text { sp. nov. }\end{array}$ & $\begin{array}{l}\text { bess beetles (Passalidae); scarab } \\
\text { beetles (Scarabaeidae) }\end{array}$ & $\begin{array}{l}\text { (Fuentefria et al., } \\
\text { 2008) }\end{array}$ \\
\hline $\begin{array}{l}\text { Trichosporon } \\
\text { mycotoxinivorans } \\
\text { sp. nov. }\end{array}$ & lower termite (Mastotermitidae) & (Molnar et al., 2004) \\
\hline $\begin{array}{l}\text { Trichosporon xylopini } \\
\text { sp. nov. }\end{array}$ & $\begin{array}{l}\text { darkling beetles (Tenebrionidae); } \\
\text { bess beetles (Passalidae) }\end{array}$ & (Gujjari et al., 2010) \\
\hline $\begin{array}{l}\text { Wickerhamomyces } \\
\text { anomalus (Pichia anomala) }\end{array}$ & mosquitoes (Culicidae) & (Ricci et al., 2011a) \\
\hline
\end{tabular}

Table 1. Yeasts detected in the alimentary tract of insects 
oral cavity (Hansen \& Klotz, 2005). Based on physiological characteristics using a microbial identification system BIOLOG, Mankowski \& Morrell (2004) identified 19 species from 155 yeast isolates collected from nest, surrounding soil and frass as well as from exoskeleton and infrabuccal pockets of carpenter ants. From 17 isolates found in the infrabuccal pockets, ten were identified as Debaryomyces polymorphus and other species (Pichia guilliermondii, Candida ergatensis, Candida edax, Bulleromyces spp. and Cryptococcus laurentii) occurred only once or twice. Besides of soil samples, D. polymorphus was the most often isolated yeast from the all analysed materials. Further social insects, such as termites may harbour high yeasts' numbers (107-108 cells $/ \mathrm{ml})$ in their gut (Schäfer et al., 1996). Schäfer et al. (1996) cultured 35 yeast isolates from the intestinal contents of termite species, Zootermopsis nevadensis and Neotermes castaneus, but the authors reported presence of only 15 yeast strains, as their enzymatic activity were significant to the study. These phenotypes were related to the genera Candida, Sporothrix, Pichia and Debaryomyces. In another study, Debaryomyces hansenii and Sporothrix albicans as well as species of Trichosporon and Rhodosporidium could also be found in the hindgut of the termites from families: Mastotermitidae, Hodotermitidae, Kalotermitidae and Rhinotermitidae and roaches (Prillinger et al., 1996).

\subsubsection{Yeasts associated with the gut of some pests}

In the gut of some maize' pests (Diabrotica virgifera, Helicoverpa armigera and Ostrina nubialalis), Molnar et al. (2008) isolated 97 yeast strains; furthermore they detected yeasts as well as other fungi of the genera: Acremonium, Aspergillus, Cladosporium and Fusarium by means of cloning and denaturing gradient gel electrophoresis (DGGE). The occurence of clones was given in percents. All methods reveald that Metschnikowia spp., closely related to Metschnikowia pulcherrima, Cryptococcus spp. (Cr. Luteolus, Cr. zeae and Cr. flavescens) as well as Candida spp., bearing close similarity to C. xestobii or C. sake, and Pseudozyma spp. were the most frequently identified yeasts. Pichia guiliermondii and Rhodotorula species were less common. Some of occassionaly found yeasts e.g. Aureobasidium pullulans, Candida quercitrusa, Hanseniaspora uvarum, Sprobolomyces coprosmae, Tilletiopsis washingtonensis were detected however only via culturing. There are some publications reporting presence of the yeasts in the gut of mosquitos (Diptera: Culicidae), which are known to be vectors of many diseases in humans. Gusmão et al. (2007; 2010) identified Pichia caribbica, Pichia guilliermondii, Pichia (syn. Kodamaea) ohmeri, Candida fermentati and Candida nodaensis in the diverticulum of Aedes aegypti. Ricci et al. (2011a) investigated yeasts in the gut of Anopheles stephensi using molecular and cultivation-dependent methods. Forty six clones that expressed fragments of the $18 \mathrm{~S}$ rRNA gene retrieved from the gut samples of 6 adults were sequenced. Eleven clones were identified as Wickerhamomyces anomalus, known also as Pichia anomala, while others could be assigned either to genus Candida or Pichia or to unidentified fungus. Moreover, 100 colonies were cultured from 10 insect speciemens, classified based on their morphology and identified as Candida intermedia, Hanseniaspora uvarum and $W$. anomalus (77\%, $15 \%$ and $8 \%$ respectively) by sequencing analysis of $18 \mathrm{~S}$ and $26 \mathrm{~S}$ rRNA genes and ITS fragments. $W$. anomalus was detectable using both approaches. Furthermore, Ricci et al. (2011a; 2011b) observed the presence of $W$. anomalus in the midgut of different mosquitos species Anopheles stephensi, Anopheles gambiae, Aedes albopictus and Aedes aegypti of both sexes as well as on larvae, pupae and gonads, thereby supposed close relationship between this yeast species and mosquitos. 


\subsubsection{Yeasts in the digestive tract of lacewings}

Lacewings (Neuroptera: Chrysopidae) are one of the predators admitted as biological control agents of pests. During the scanning and transmission electron microscopical studies, a large numbers of yeast cells were observed within lacewings' alimentary tract (Woolfolk et al., 2004; Woolfolk \& Inglis, 2004; Chen et al., 2006). Woolfolk \& Inglis (2004) investigated yeasts in the different parts: diverticulum, foregut, midgut, and hindgut of digestive tract of 24 lacewing adults (Chrysoperla rufilabris) collected at two field locations in Mississippi. With the exception of 7 insects that were yeasts-free, lacewings harboured a high concentration $(\approx$ $10^{3}$ colony forming units; $\mathrm{CFU}$ ) of yeasts distributed in the all analysed gut sections; however the highest $\left(5.4 \times 10^{5} \mathrm{CFU} / \mathrm{g}\right)$ density was in diverticulum. In total 752 yeasts were isolated in the study and arranged in five groups based on their phenotypic properties; some specimens were randomly chosen from each group for further genotyping analysis. Interestingly, $89 \%$ of the isolates were identified as Metschnikowia pulcherrima and the remaining $11 \%$ involved either Cryptococcus victoriae or Cryptococcus luteolus or strains that could not be assigned by the authors to any known species. Sometimes, closely related yeast species could be separated only according to the genotypic characterization, while they were showing similar physiological properties (Kurtzman \& Fell, 2006) as it was the case in the study of Suh et al. (2004a). These authors isolated 14 yeasts from digestive tract of Chrysoperla spp. which were closely related to M. pulcherrima, however sufficiently variable in the D1\&D2 domains of the 26S rRNA gene of the large subunit (LSU) to represent three new species: Metschnikowia chrysoperlae, Candida picachoensis and Candida pimensis. Recently, several new yeasts of Metschnikowia and Candida (see table 1) were discovered in the gut of other members of the Neuroptera, too (Nguyen et al., 2006; 2007).

\subsubsection{Yeasts in the digestive tract of beetles}

At the present time, the most yeasts were isolated from the digestive tract of beetles (Coleoptera). Shifrine \& Phaff (1956) collected bark beetles (Dendroctonus and Ips) and their larvae from the various coniferus trees in Northern California. After sterilization of the outer surface, the beetles were dissected and yeasts were isolated from internal parts of the insects. Total of 169 yeast strains could be assigned to 13 species. Candida silvicola (41.4\%; teleomorph Hansenula holstii), Hansenula capsulata (21.3\%), Pichia pinus (18.9\%) and Candida curvata $(8.9 \%)$ were frequently found; other species (e.g. C. parapsilosis, C. mycoderma, C. rugosa, Cryptococcus diffiuens) were rarely (from 0.6 to $1.8 \%$ ) isolated. Some yeasts as Candida (Torulopsis) nitratophila, C. (T.) melibiosum, Rhodotorula crocea and C. silvicola were described by these authors as new species. Recently, Rivera et al. (2009) provided an account of yeasts associated with alimentary tract of Dendroctonus beetles. Yeasts (403 strains) were isolated from different parts of intestine, the midgut (anterior \& posterior) and the hindgut, as well as from the ovaries, eggs and frass of the beetles collected from pine trees at 34 locations in Mexico, Cuatemala and the USA. Based on the sequence analysis of several DNA regions (18S, 26S rRNA genes and ITS1) and phenotypical characteristics, the yeasts were reletated to three genera: Candida spp. (C. ernobii, C. piceae, C. membranifaciens, C. lessepsii, C. arabinofermentans and C. oregonensis), Pichia spp. (P. americana, P. guilliermondii, $P$. scolyti, $P$. mexicana, P. glucozyma and $P$. canadensis) and Kurashia spp. (K. capsulata and K. cf. molischiana). The exact numbers of the yeast strains isolated from the different gut sections have not been provided by the autors, however, they indicated that yeasts were present in eggs, ovaries and frass to much lesser extent than in the guts. For instance, P. americana, $C$. 
ernobii and the strains related to the one Candida sp. were prevalent in all parts of gut and frass and P. guilliermondii and C. ernobii were cultured most frequently from the posterior midgut.

In relation to high number of the yeast isolates (richness) described above, comparatively low yeast diversity was found in the assemblage of Dendroctonus beetles. It thereby underlined the impact of the host and/or environmental factors on the yeasts diversity. Nevertheless, examination of yeasts harbouring the GIT of beetles from 27 families reviled a huge variety of yeasts (Suh et al., 2005a).

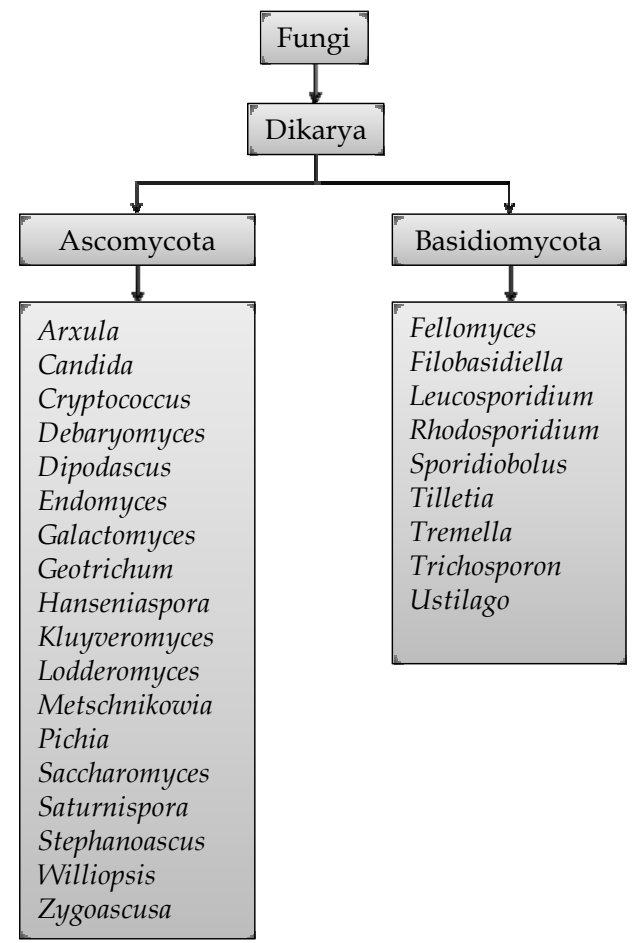

Fig. 1. Schematic representation of the different yeast taxa belonging to the two phyla Ascomycota and Basidiomycota of the Dikarya subkingdom isolated from the intestinal tract of insects during the study of Suh et al. (2005a).

During three-years-period, Suh et al. (2005a) isolated about 650 yeasts from the gut of diverse beetles collected from the south-eastern USA and Panama. Sequence analyses of the D1\&D2 domains of LSU rRNA gene revealed 290 single species belonging to at least 27 taxa (Fig. 1.); the great majority of which were ascomycetous and some basidiomycetous yeasts. It is noteworthy that nearly 200 yeasts determined throughout the study were considered by the authors to represent new, not yet described species. In the meantime, some of them (table 1) were characterized by Suh, Nguyen, Blackwell and their co-workers. Based on their observation Suh et al. (2005a) suggested that almost each beetle species may be a host for at least one unknown yeast species. In the last decades, describing of many novel species of yeasts isolated from the gut of insects corroborates this supposition. 
Nowadays, there are over one million of accepted insect species; however, their number has yearly increased and is still largely undiscovered (Chapman, 2009). Thus, it can be supposed that the number of yeasts would tremendously rise, even if only the intestinal tracts of the currently known insects were explored.

\subsection{Yeasts' diversity in the GIT of vertebrates with focus on farm animals}

The more intensive investigations of the yeast population present in the GIT of vertebrates, based on various cultivation procedures, began in the fifties of the $X X^{\text {th }}$ Century. Van Uden et al. (1958) and Van Uden \& Carmo Sousa (1957b) examined yeasts in the caecal samples of large number of animals: 252 cattle, 252 horses, 503 sheep, 250 goats and 250 pigs. Yeasts were also studied by Parle (1957) in the digestive tract of cows, rabbits, sheep, guinea pigs, opossums, monkeys, cats, dogs, hedgehogs, mice, pigs and rats. Lund (1974) explored yeasts and moulds in the bovine rumen. Lately, yeasts were also described in the intestinal tract of reptiles (Kostka et al., 1997), birds (Cafarchia et al., 2006; 2008; Brilhante et al., 2010; Costa et al., 2010), mice (Scupham et al., 2006), dogs (Brito et al., 2009) and fish (Gatesoupe, 2007). In these studies, the scientists have detected various ascomycetous and basidiomycetous yeasts chiefly representing the genera Candida, Trichosporon, Pichia, Rhodotorula, Debaryomyces, Kluyveromyces and Saccharomyces.

In general, the diversity of the yeast population depended on the host; but many species occurred at diverse, also not intestinal ecosystems; and several exhibited direct relationship to the individual animal. It should be noticed, however, that yeasts could not be always isolated from the investigated GIT and often they were present in small numbers. Nevertheless, taking into consideration the scarce information existing on yeasts in the gastrointestinal ecosystems of vertebrates, it is well known that relatively high variety as well as quantity of yeasts can be found in the GIT of pigs.

Here, the yeasts diversity in the GIT of farm animals representing diverse nutritional types: omnivores (pig), monogastric herbivores (horse) and ruminants will stay in focus and will be compared.

\subsubsection{Yeasts in the GIT of pigs}

Comparatively to all animals investigated in the study of Van Uden et al. (1958), the most frequent occurrence $(88.8 \%)$ of yeasts was detected in the caecum of pigs (horses $52.4 \%$, cattle $46.8 \%$, sheep $6.8 \%$, and goats $6.4 \%$ ). The yeasts Candida slooffiae, Candida krusei, Saccharomyces telluris, Candida albicans, Candida (Torulopsis) glabrata, were commonly found in the porcine gut. However, C. slooffiae was isolated most frequently (48.4\%). A few other yeasts such as Saccharomyces spp., Pichia membranifaciens, Pichia farinose and Candida mycoderma could also be identified. Roughly the same situation has been confirmed in the following studies (Van Uden \& Carmo-Sousa, 1962; Mehnert \& Koch, 1963), where the scientists isolated almost the same variety of yeasts from the different parts of porcine GIT. After investigation of digesta samples collected from stomach, three parts of small intestine as well as caecum and rectum of healthy 57 pigs, Van Uden \& Carmo Sousa (1962) reported high animal-individual qualitative and quantitative variability if the yeast occupation. In total 15 yeast species were identified; while $C$. slooffiae was present in 27 pigs, many other species mentioned above occurred only sporadically. Moreover, C. slooffiae was highly abundant, from $10^{2}$ to $10^{3} \mathrm{CFU} / \mathrm{g}$ of chyme in the stomach and up to $10^{6} \mathrm{CFU} / \mathrm{g}$ intestine contents in the rectum. A still higher occurrence of yeasts in the gut of pigs was detected by Mehnert \& Koch (1963), up to $10^{7} \mathrm{CFU} / \mathrm{g}$ in rectum. They isolated 292 yeasts from 200 
digesta samples collected from stomach and rectum from 98 (of 100 examined) pigs. Apart from the C. slooffiae which was detectable in $75 \%$ of pigs, yeast species such as C. krusei, $S$. telluris, C. albicans, C. glabrata, C. tropicalis, C. parapsilosis and C. pintolopesii $(60 \%, 26 \%, 9 \%$, $4 \%, 3 \%, 3 \%$ and $2 \%$ respectively) were isolated, too. Also in this study the appearance of yeasts was variable within a part of the GIT and among examined animals. Thus, stomach was generally colonized by yeasts at lesser intense than rectum. In most animals, C. slooffiae and C. krusei were detected both in stomach and rectum, while just in a few cases the yeasts could be found only in a single part of the GIT. C. slooffiae and its closely related species: $S$. telluris and C. pintolopesii have been newly molecularly investigated and based on multigene sequence analyses they were assigned to the teleomorphic genus Kazachstania (Kurtzman et al., 2005).

Recently, Urubschurov et al. (2008) described yeasts' diversity in the gut of piglets around weaning which were reared at two facilities: at experimental farm (EF) with improved husbandry conditions than at commercial farm (CF). Most piglets, 33 at CF and 35 at EF, were weaned at 28 days (d) of age and fed with the same diet until $39 \mathrm{~d}$ in both farms. A number of piglets, namely 18 at $\mathrm{CF}$ and 9 at EF, were left by the sows without additional feeding. All piglets were sacrificed at $39 \mathrm{~d}$ of age and digesta samples from GIT were collected. D1\&D2 domains of $26 \mathrm{~S}$ rRNA gene from 173 yeast isolates obtained from 95 piglets were sequenced. The alignment to known sequences revealed close relationship to 17 species, of which the most dominated are presented in figure 2. Urubschurov et al. (2008) observed distinction of yeasts variety between both facilities that were proven by calculation of different similarity and diversity indices. In piglets from CF Galactomyces geotrichum, Kazachstania slooffiae and Candida catenulata were the most abundant ones and the other were present only at low abundances. Unlike at CF, at EF two species, namely K. slooffiae and C. glabrata were found to be the most dominating ones and the others were rarely isolated. Some of the other species could be found in piglets either only at the EF (P. fermentans, C. tropicalis, C. oleophila, C. parapsilosis, P. guilliermondii, Rh. mucillaginosa, T. montevideense) or at the CF (C. silvae and P. farinose). This study provided evidence for association of $K$. slooffiae with the porcine GIT. K (C.) slooffiae was found for the first time in 6 of 252 examined horses (Van Uden \& Carmo-Sousa, 1957a), however, due to frequent occurrence and high concentration in the porcine digestive tract it can be considered to be specific for pigs.

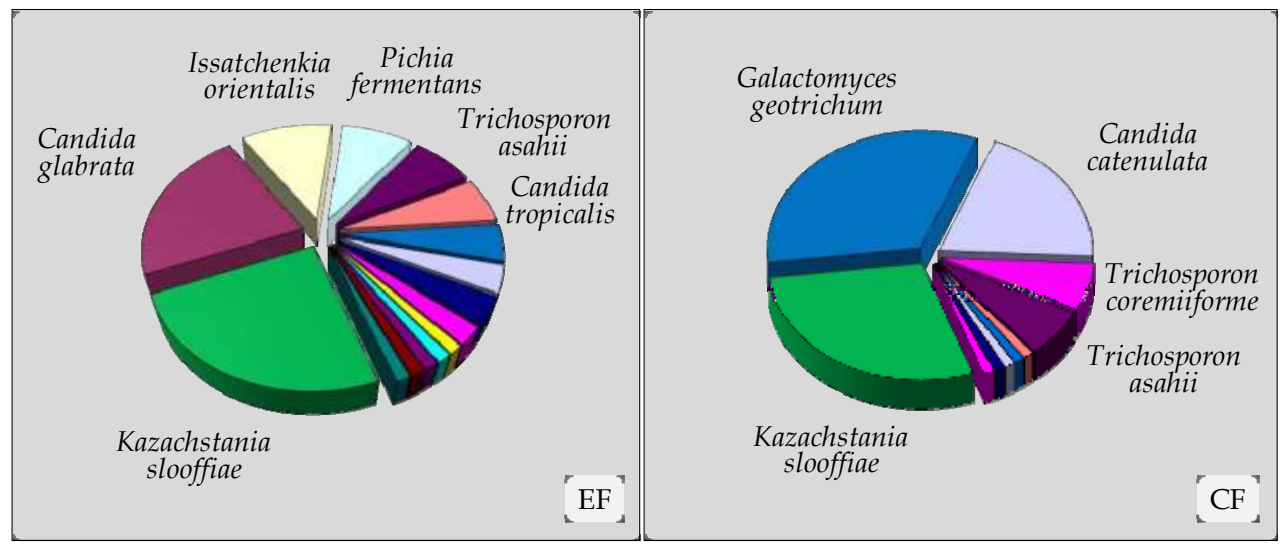

Fig. 2. Dominated yeasts isolated from the gut of $39 \mathrm{~d}$ old piglets, kept at experimental (EF) and commercial farm (CF), in the study of Urubschurov at al. (2008). 
Furthermore, compared to other yeasts occurring in the porcine GIT, which can survive also in other ecological niches outside the animals, $K(C$.) slooffiae seems to be well adapted to the porcine gastrointestinal habitat, as this species is one of those that need high temperature to grow, comparable to the temperature of animal body, being characterized as thermophilic or psychrophobic (Travassos \& Cury, 1971).

\subsubsection{Yeasts in the equine GIT}

Several investigators focused on the effect of yeast, Saccharomyces cerevisiae, on intestinal microbiota of horses and on the digestibility of different diets (e.g. Medina et al., 2002; Jouany et al., 2008; 2009). But little is known about the yeasts naturally occurring in the equine gut. Van Uden et al., (1958) studied yeasts in the caecal contents of 252 horses, and these authors revealed presence of yeasts in over half $(52.4 \%)$ of the investigated animals. With occurrence of $21.8 \%$, Trichosporon cutaneum was the most frequently isolated yeast, whereas in porcine intestine this species was found only one time. However, other yeasts: $C$. krusei $(8.3 \%)$ as well as C. tropicalis $(4.4 \%)$, C. albicans $(4.4 \%)$, C. parapsilosis (3.6\%), C. slooffiae $(2.4 \%)$, C. glabrata $(1.2 \%)$ and S. telluris $(1.2 \%)$ detected in the GIT of horses were also commonly recorded in pigs.

\subsubsection{Yeasts in the GIT of ruminants}

As reported by Lund (1974), a different number of yeasts has been observed in the ruminal contents from cows and sheep depending on the culture conditions and incubation temperature. After at $39^{\circ} \mathrm{C}$ incubation of the rumen contents collected at different times from five cows, Clarke \& Menna (1961) quantified yeast colonies rated from 80 to 13,000 per gram of samples; 134 colonies were isolated for further characterization. Yeasts from Candida spp. (C. krusei, C. albicans, C. tropicalis and C. rugosa), Trichosporon spp. (T. cutaneum and T. sericeum) and Rhodotorula spp. (Rh. rubra/mucilaginosa, Rh. glutinis and Rh. macerans) were identified; however, the Rhodotorula spp. could be cultured only at the temperature of $19^{\circ} \mathrm{C}$. Lund (1974) examined fungal microbiota in rumen liquid of 10 fistulated and 2 non fistulated cows fed different diets. Forty nine collected samples were plated and incubated simultaneously at $25^{\circ} \mathrm{C}$ and at $39^{\circ} \mathrm{C}$. A considerably larger number of yeast colonies, up to 1000 fold and about 20 fold on average, were observed after incubation at $25^{\circ} \mathrm{C}$, while sometimes even none could be obtain after incubation at $39^{\circ} \mathrm{C}$. Nevertheless, only 67 yeast isolates growing at $39^{\circ} \mathrm{C}$, as it is the temperature proper to the rumen environment, were used for further identification. The largest share (77.6\%) of them was identified as C. krusei, T. cutaneum and $T$. capitatum and the rest were C. valida, C. ingens, C. pintolepesii, Klyveromyces bulgaricus, Saccharomycopsis lipolytica and Hansenula fabianii. Other fungi (molds) belonging to the order Mucorales have been also found in the study. Additionally, Lund (1974) observed two yeast species C. krusei and T. capitatum in faeces of the cattle. However, their counts were lower than in the rumen samples of corresponding host. Later, Lund (1980) conducted a similar study where the researcher investigated yeasts microbiota in 16 rumen samples of musk oxen. Only 6 strains of one species, C. parapsilosis were identified after incubation at $37^{\circ} \mathrm{C}$, while 41 yeast strains belonging to Candida spp., Cryptococcus spp., Trichosporon spp., Rhodotorula spp., Torulopsis spp. and Pichia spp. were characterized after growing at $25^{\circ} \mathrm{C}$. But, the authors indicated that the rumen contents were kept frozen for a long period (more than 7 weeks), what could have had considerable effects on yeast colonization. As mentioned above, Van Uden et al. (1958) cultivated caecal samples 
from a much higher number of cattle (252) as well as sheep (503) and goats (250). Among the investigated animals, cattle showed the highest (46.8\%) occurrence of yeasts, whereas just a few yeasts could be found in sheep and goats, $6.8 \%$ and $6.4 \%$ of the animals, respectively. The most frequently isolated yeasts were C. tropicalis and C. krusei in cattle, and C. albicans in sheep. These species were also isolated from the goats, but just two times each; and $C$. glabrata four times. A few other yeasts identified as members of Saccharomyces spp., Candida spp. and Pichia spp. have been found only occasionally.

Quite similar results regarding yeast colonization have been obtained in the cultivation dependent studies (Clarke \& Menna 1961; Lund 1974; 1980; Van Uden et al. 1958) from different geographical regions. Shin et al. (2004) explored different rumen samples (fluid, solid and epithelium) from one cow, examined for yeasts population using molecular approaches. Shin et al. (2004) have succeeded to obtain 97 clones containing 26S rRNA gene fragments from the three types of samples and to assign them to the different phylogenetic groups. Compared to 4 phylotypes from the rumen epithelium showing the closest relatedness to Geotrichum silvicola, Acremonium alternatum, Pseudozyma rugulosa (up to 99\%) and Galactomyces sp. (97\%), and 2 phylotypes (Geotrichum silvicola, 99\% and Galactomyces sp., $97 \%$ ) from the rumen solid, the highest yeast' diversity was observed in the samples of rumen fluid revealing presence of 15 various phylotypes. Only 5 (Setosphaeria monoceras, Raciborskiomyces longisetosum, Magnaporthe grisea, Ustilago affinis and Pseudozyma rugulosa) of the 15 phylotypes showed $99 \%$ identity with the sequences deposited at the NCBI GenBank. The identification rate of the others belonging also to the classes Pezizomycotina, Urediniomycetes, Saccharomycotina and Hymenomycetes ranged from 91 to $98 \%$. These phylotypes could represent new species, because in yeasts more than $1 \%$ of the nucleotide divergence in D1\&D2 domains of the 26S rRNA gene may represent a separate species (Kurtzman \& Fell, 2006). In spite of the lack of inter-individual comparison, this study showed a potential existence of the other yeasts that have not been discovered yet.

\section{Methods for investigating biodiversity of the yeasts from GIT}

From the cited references it is obvious, the biodiversity studies depend very much on the applied method. However, this is beyond the scope of this chapter to provide very detailed description of all possible methods that could be used for studies on yeasts' diversity. Nor calculation of the different biodiversity indices is in the focus of the paragraph. This paragraph is meant to provide short discussion on the existing possibilities, their limitations and advantages, and provide the reader with some input for consideration which methods he or she would choose for his/her studies.

Any application of either method mentioned below requires correct sampling of the material. Studying the biodiversity of the yeasts harbouring the GIT the dominating yeasts are in focus of most studies, as well as their abundance and changes of the abundance in time and in relation to the diet. For these purposes faecal or digesta samples have been collected from large animals (Urubschurov et al., 2008; 2011) or whole intestines from e.g. insects have been dissected (Suh et al., 2004b; 2005a; Nguyen et al., 2007). Whereas rain worms, termites or other small animals can provide the whole GIT for the studies, only part of contents of wall of the GIT can be studied in large animals. Therefore the choice of sampling is the first bottle neck in the studies on yeasts biodiversity in the GIT. Following proceedings such as homogenization, concentration or dilution of the samples must be hereby additionally considered. 
Among the methods applied for investigating the biodiversity of yeasts harbouring the GIT of animals, cultivation and morphological and/or biochemical identification have been the most often used for more than 150 years. However, these methods bear limitations such as the choice of the right cultivation medium, $\mathrm{pH}$, temperature and moisture. Furthermore the yeast species that need more time for growth and are at lower abundance in the community cannot be identified in this way. It has been accepted that every ecosystem consists, next to cultivable organisms, also of viable but non-cultivable (VBNC) microorganisms, that contemporarily cannot be cultivated in laboratory because of nutrient limitation or lack of optimal living conditions (Edwards, 2000). This is why only approximately $1 \%$ of yeast species could be described so far (Kurtzman \& Fell, 2006). Sabouraud agar is the medium most commonly used for cultivation of yeasts from clinical or ecological samples (Odds, 1991), however many others have been used for industrial purposes, providing alternatives for cultivation of more demanding species (King et al., 1986; Jarvis \& Williams, 1987; Fleet, 1990; Deak, 1991). It is to remember, that various species can give similar colonies, and the same species can grow in a different way under different conditions. Cultivated species can be however observed under microscope, what helps for identification of the isolates. Spectrophotometric methods such as MALDI-TOF could also provide fast and good tool for identification of the isolates. Molecular methods can be also applied for identification of isolates, e.g. pyrosequencing of target genes (Borman et al., 2009; 2010). Further development of modified media and combinations of temperature, $\mathrm{pH}$, aerobic/anaerobic conditions and moisture would probably increase the number of isolated yeasts, it is however laborious and very time consuming.

Cultivation-independent methods which have been used for the last two decades provided the researches with fast and specific tools for the biodiversity studies. Polymerase chain reaction (PCR), DNA-DNA hybridization or fluorescence in situ hybridization (FISH) applying probes targeting the RNA allow in theory detection of 1 single colony present in a sample population. Further separation of the specific DNA fragments performing denaturing or temperature gradient gel electrophoresis (DGGE / TGGE) allows studying the diversity of the complex community (Cocolin et al., 2002; Prakitchaiwattana et al., 2004; Molnar et al., 2008). Other molecular methods could be also applied for identification of members of a community, e.g. terminal restriction fragment length polymorphism (T-RFLP), amplified fragment length polymorphism (AFLP), multiple-locus variable number tandem repeat analysis (MLVA) (e.g. Tiedje et al., 1999; Gemmer et al., 2002). These methods are very specific, allowing targeting of specified species and thus quantification of the yeasts and calculating the biodiversity. The largest limitation for methods based on PCR is the low sensitivity, as the practice shows only $1-2 \%$ of the community can be detected in this way (Macnaughton et al., 1999). Furthermore, fingerprint methods have the bias combined to the fact that amplicons form different species with sequences of similar energetic profile may migrate to the same positions; multiple gene copies with slight sequence differences may give multiple bands for one strain or species; finally some species are phylogeneticaly very similar (Lachance et al., 2003; Janczyk et al., 2006; Borman et al., 2010). The design of probes for direct targeting needs knowledge on the sequence of the target gene and differences between species.

Pyrosequencing and other high-throughput methods provide a fast and very efficient tool for identification of the members of the complex populations. Metagenome analyses targeting the D1/D2 domain of the 26S rRNA gene or the internal transcribed regions (ITSs) allow distinction of the yeasts (Kurtzman \& Fell, 2006) and seem to be very suitable methods 
for studying the yeast biodiversity in the GIT of animals. Pyrosequencing is a rapid method providing up to several thousands of sequences per sample in just few days. Followed by bioinformatics processing, alignment to known species is performed resulting not only in a phylogenetic tree but also in description of the species diversity. Unknown species can be also detected in this way. The high cost provides the limitation for the wide application of this method; however it is to expect that in the near future the high-throughput sequencing will be as expensive as the other commonly used molecular tools.

A microarray has been recently developed allowing characterization of pig GIT bacterial community, targeting over 800 phylotypes (Pérez Gutiérrez, 2010). Microarrays for yeasts would need to be developed to provide further molecular tool for studying the biodiversity and its changes caused by different extrinsic factors.

\section{Role of yeasts in GIT}

Studying diversity of yeasts harbouring the GIT of animals would be incomplete without consideration of the role that these microorganisms play for the host. For years the yeasts harbouring the GIT of animals and humans have been considered rather as harmful to the host's health. Indeed, there are some species belonging to Candida, Cryptococcus, Malassezia, Trichosporon and Geotrichum that could be pathogenic to members of the Animal kingdom (Fidel et al., 1999; Girmenia et al., 2005; Cabañes, 2010). Furthermore, many researchers have evaluated yeasts in association with various diseases and if they found representatives of this group they acted against them applying medical treatment (Schulze \& Sonnenborn, 2009). However, there is just as little known about yeasts harbouring the GIT of healthy animals to understand their importance there, and growing evidences appear for their role in the proper function and survival of the host. In fact, the current knowledge about yeasts in the digestive tract of vertebrates is still based on the findings from 50's and 70's of the $X X^{\text {th }}$ Century; therefore there is a great demand for the scientific evaluation in this field. As enough reports exist concerning pathogenic yeasts, in this paragraph a possible positive impact of yeasts on the gut ecology and host health will be discussed.

There are nice reviews (e.g. Phaff \& Starmer, 1987; Ganter, 2006) pronouncing a yeast-insect relationship. Gatesoupe (2007) gave an insight into the ecology of yeasts naturally occurring in the intestinal tract of fish, and thereby emphasized a possible importance of yeasts to the host.

Similarily to the probiotic strains of Saccharomyces cerevisiae (Buts, 2009), the cells of some intestinal yeasts could have a trophic effects since they provide a source of B vitamins, proteins, trace minerals and essential amino acids. Besides, the major portion $(>90 \%)$ of the yeast cell walls comprise of polysaccharides such as $\beta$-glucans, mannans and chitin, which composition and structure are specific for individual yeast (Latgé, 2007). In many human and animals studies, $\beta$-glucans and mannans have been comprehensively investigated; they may play important diverse roles for the host immune system and exhibit antimicrobial activity against bacteria thereby influencing the establishment of the intestinal microbiota and promising to promote host's health. Therefore, several studies concentrated on use of the live or dead yeast cells in human and animal nutrition as supplements or as a remedy for acute diarrhoea in humans (Bekatorou et al., 2006; Buts \& De Keyser, 2006; Fleet, 2007; Buts, 2009). Furthermore, due to production of several enzymes, some yeast species, e.g. found in the gut of termites (Schäfer et al., 1996; Molnar et al., 2004) and beetles (Suh et al., 2003), are able to degrade hemicelluloses that are being the main carbohydrates of 
herbivorous diet, and also detoxify toxins that can appear in the feed. The possibility cannot be excluded that some yeasts harbouring GIT of herbivorous animals may produce extracellular enzymes (e.g. exohemicellulases, exocellulases) or show endocellulolytic activity, and thereby contribute to their digestion by braking down complex, indigestible fibre into simple carbohydrates.

It is still a prevalent opinion, that yeasts harbouring the digestive tract of animals have only minor importance for the host. The main scientific argument up to date is the negligible quantity of yeasts. Nevertheless, yeasts may be of physiological relevance, even though they are present to a much lesser extent than bacteria. In fact, yeasts could provide a relevant biomass, as their have a cell volume 30- to 100-fold higher than bacteria (Gatesoupe, 2007). Commensal yeasts may interact with intestinal bacteria and due to this interplay affect microbial diversity and host organism. An example of such yeasts-bacteria interrelationship provides the study of Urubschurov et al. (2011) who examined changes of yeasts and major bacterial groups (lactobacilli, enterobacteria and enterococci) in the faeces of piglets after weaning. They observed that the increase of yeasts number, where the dominating species was Kazachstania slooffiae, significantly correlated with the increase of lactobacilli and decrease of enterobacteria numbers. Other studies hypothesized that specific yeasts frequently occurred in high quantity at the digestive tract of lacewings (Woolfolk \& Inglis, 2004; Woolfolk et al., 2004) and mosquitoes (Ricci et al., 2011a; 2011b) and were symbiotically related to the host.

These first indications need further confirmation but they already show that the yeasts cannot be considered negligible any more.

\section{Conclusions}

Yeasts belong to gastrointestinal microbiota even though they are not as frequent as the bacteria or archea. However, it does not disclude their importance for the host and for the members of the complex microbial community. Despite long time of research, whereas our knowledge on bacterial intestinal communities has increased dramatically during last decade, still only little is known on the intestinal yeasts. This review provides an overview on what has been done in the field of intestinal yeast research up till now, and the reader surely agrees that much more work needs to be done. Not only the diversity of the intestinal yeasts and its changes depending on different conditions shall be further uncovered. The importance of yeasts for the host and the interplay between yeasts and other members of the intestinal milieu is also waiting to be explored. New cultivation techniques; cultivation combined with molecular techniques will need to be further developed to overcome the existing limitations.

\section{References}

Batra, L.R., Batra, S.W.T. \& Bohart, G.E. (1973). Mycoflora of Domesticated and Wild Bees (Apoidea). Mycopathol Mycol Appl, Vol.49, No.1 (August 2005 in SpringerLink), pp. 13-44, ISSN: 0027-5530.

Bauer, E., Williams, B.A., Smidt, H., Verstegen, M.W., \& Mosenthin, R. (2006). Influence of the gastrointestinal microbiota on development of the immune system in young animals. Curr Issues Intest Microbiol, Vol.7, No.2, pp. 35-51.

Bekatorou, A., Psarianos, C. \& Koutinas, A.A. (2006). Production of food grade yeasts. Food Technol. Biotech. Vol.44, No.3, pp. 407-415, ISSN: 1330-9862. 
Borman, A.M., Linton, C.J., Oliver, D., Palmer, M.D., Szekely, A., Odds, F.C. \& Johnson, E.M. (2009). Pyrosequencing analysis of 20 nucleotides of internal transcribed spacer 2 discriminates Candida parapsilosis, Candida metapsilosis, and Candida orthopsilosis. J Clin. Microbiol., Vol.47, No.7 (July 2009), pp. 2307-2310, ISSN: 00951137.

Borman, A.M., Linton, C.J., Oliver, D., Palmer, M.D., Szekely, A. \& Johnson, E.M. (2010). Rapid molecular identification of pathogenic yeasts by pyrosequencing analysis of 35 nucleotides of internal transcribed spacer 2. J Clin. Microbiol., Vol.48, No.10 (October 2010), pp. 3648-3653, ISSN: 1098-660X.

Botha, A. (2006). Yeasts in Soil. In: The Yeast Handbook: Biodiversity and Ecophysiology of Yeasts, C.A. Rosa \& G. Peter (Ed.), pp. 221-240, Springer-Verlag, ISBN-10: 3-540-26100-1, Berlin Heidelberg.

Brilhante, R.S., Castelo-Branco, D. S, Soares, G.D., Astete-Medrano, D.J., Monteiro, A.J., Cordeiro, R.A., Sidrim, J.J. \& Rocha, M.F. (2010). Characterization of the gastrointestinal yeast microbiota of cockatiels (Nymphicus hollandicus): a potential hazard to human health. J Med. Microbiol., Vol.59, No.Pt6 (June 2010), pp. 718-723, ISSN: 0022-2615.

Brito, E.H., Fontenelle, R.O., Brilhante, R.S., Cordeiro, R.A., Monteiro, A.J., Sidrim, J.J. \& Rocha, M.F. (2009). The anatomical distribution and antimicrobial susceptibility of yeast species isolated from healthy dogs. Vet. J, Vol.182 No.2, (November 2009), pp. 320-326, ISSN: 1090-0233.

Brysch-Herzberg, M. (2004). Ecology of yeasts in plant-bumblebee mutualism in Central Europe. FEMS Microbiol. Ecol., Vol.50, No.2 (November 2004), pp. 87-100, ISSN: 1574-6941.

Buts, J.P. \& De Keyser, N. (2006). Effects of Saccharomyces boulardii on intestinal mucosa. Dig. Dis. Sci., Vol.51, No.8, pp. 1485-1492, ISSN: 0163-2116.

Buts, J.P. 2009. Twenty-five years of research on Saccharomyces boulardii trophic effects: updates and perspectives. Dig. Dis. Sci., Vol.54, No.1, pp. 15-18, ISSN: 0163-2116.

Cabañes, F.J. (2010). Yeast pathogens of domestic animals. In: Pathogenic Yeasts, The Yeast Handbook, H.R. Ashbeee \& E.M. Bingell (Ed), pp. 253-279 Springer-Verlag, ISBN 978-3-642-03149-6, Berlin Heidelberg.

Cafarchia, C., Camarda, A., Romito, D., Campolo, M., Quaglia, N.C., Tullio, D. \& Otranto, D. (2006). Occurrence of yeasts in cloacae of migratory birds. Mycopathologia, Vol.161, No.4 (March 2006), pp. 229-234, ISSN 0301-486X.

Cafarchia, C., Romito, D., Coccioli, C., Camarda, A. \& Otranto, D. (2008). Phospholipase activity of yeasts from wild birds and possible implications for human disease. Med Mycol, Vol.46, No.5, pp. 429-434, ISSN 1369-3786.

Carreiro, S.C., Pagnocca, F.C., Bueno, O.C., Bacci, M.B., Hebling, M.J.A. \& da Silva, O.A. (1997). Yeasts associated with nests of the leaf-cutting ant Atta sexdens rubropilosa Forel, 1908. Anton. Leeuw. Int. J. G., Vol.71, No.3 (October 2004 in SpringerLink), pp. 243-248, ISSN 0003-6072.

Chapman, A.D. (2009). Numbers of Living Species in Australia and the World. 2nd ed. Australian Biological Resources Study, Canberra, pp. 66.

Chen, T.Y., Chu, C.C., Hu, C., Mu, J.Y., \& Henneberry, T.J. (2006). Observations on midgut structure and content of Chrysoperla carnea (Neuroptera: Chrysopidae). Ann. Entomol. Soc. Am., Vol.99, No.5 (September 2006), pp. 917-919, ISSN: 0013-8746. 
Clarke, R.T. \& Menna, M.E.D. (1961). Yeasts from Bovine Rumen. J. Gen. Microbiol., Vol.25, No.1, pp. 113-117, ISSN: 0022-1287..

Cocolin, L., Aggio, D., Manzano, M., Cantoni, C. \& Comi, G. (2002). An application of PCRDGGE analysis to profile the yeast populations in raw milk. Int. Dairy J., Vol.12, No.5, pp. 407-411, ISSN: 0958-6946.

Costa, A.K.F., Sidrim, J.J.C., Cordeiro, R.A., Brilhante, R.S.N., Monteiro, A.J. \& Rocha, M.F.G. (2010). Urban Pigeons (Columba livia) as a Potential Source of Pathogenic Yeasts: A Focus on Antifungal Susceptibility of Cryptococcus Strains in Northeast Brazil. Mycopathologia, Vol.169, No.3 (October 2009 in SpringerLink) pp. 207-213, ISSN: 0301-486X.

Deak, T. (1991). Foodborne Yeasts. In: Advances in Applied Microbiology, Vol.36, pp. 179-278, Academic Press, Inc., ISBN: 0-12-002636-8, USA.

Dillon, R.J. \& Dillon, V.M. (2004). The gut bacteria of insects: Nonpathogenic interactions. Annu. Rev. Entomol., Vol.49, No.1 (January 2004), pp. 71-92, ISSN: 0066-4170.

Edwards, C. (2000). Problems posed by natural environments for monitoring microorganisms. Mol. Biotechnol., Vol.15, No.3 (August 2007 in SpringerLink), pp. 211-223, ISSN: 1073-6085.

Fell, J.W., Boekhout, T., Fonseca, A., Scorzetti, G. \& Statzell-Tallman, A. (2000). Biodiversity and systematics of basidiomycetous yeasts as determined by large-subunit rDNA D1/D2 domain sequence analysis. Int. J. Syst. Evol. Microbiol., Vol.50, No.3, pp. 1351-1371, ISSN: 1466-5026.

Fidel, P.L.Jr., Vazquez, J.A. \& Sobel, J.D. (1999). Candida glabrata: review of epidemiology, pathogenesis, and clinical disease with comparison to C. albicans. Clin. Microbiol. Rev., Vol.12, No.1, pp. 80-96, ISSN: 0893-8512.

Fleet, G.H. (1990). Food spoilage yeasts. In: Yeast technology. J.F.T. Spencer \& D.M. Spencer (Ed), pp. 124-166, Springer, Berlin Heidelberg, ISBN: 3-540-50689-6, New York.

Fleet, G.H. (2007). Yeasts in foods and beverages: impact on product quality and safety. Curr. Opin. Biotechnol., Vol.18, No.2 (April 2007), pp. 170-175, ISSN: 0958-1669.

Fonseca, A. \& Inàcio, J. (2006). Phylloplane Yeasts. In: The Yeast Handbook: Biodiversity and Ecophysiology of Yeasts. C.A. Rosa \& G. Peter (Ed), pp. 263-301, Springer-Verlag, ISBN: 978-3-540-26100-1, Berlin Heidelberg.

Fuentefria, A.M., Suh, S.O., Landell, M.F., Faganello, J., Schrank, A., Vainstein, M.H., Blackwell, M. \& Valente, P. (2008). Trichosporon insectorum sp. nov., a new anamorphic basidiomycetous killer yeast. Mycol. Res, Vol.112, No.1 (January 2008) pp. 93-99, ISSN: 0953-7562.

Ganter, P.F. (2006). Yeast and Invertebrate Associations. In: The Yeast Handbook: Biodiversity and Ecophysiology of Yeasts., C.A. Rosa \& G. Peter (Ed), pp. 303-370, Springer-Verlag, ISBN: 978-3-540-26100-1, Berlin Heidelberg.

Gatesoupe, F.J. (2007). Live yeasts in the gut: Natural occurrence, dietary introduction, and their effects on fish health and development. Aquaculture, Vol.267, No.1-4 (July 2007), pp. 20-30, ISSN: 0044-8486.

Gemmer, C.M., DeAngelis, Y.M., Theelen, B., Boekhout, T. \& Dawson, T.L.J.Jr. (2002). Fast, noninvasive method for molecular detection and differentiation of Malassezia yeast species on human skin and application of the method to dandruff microbiology. $J$ Clin. Microbiol., Vol.40, No.9 (September 2002), pp. 3350-3357, ISSN: 0095-1137. 
Gilliam, M., Wickerham, L.J., Morton, H.L., \& Martin, R.D. (1974). Yeasts Isolated from Honey Bees, Apis-Mellifera, Fed 2,4-D and Antibiotics. J. Invertebr. Pathol., Vol.24, No.3 (November 1974), pp. 349-356, ISSN: 0022-2011.

Girmenia, C., Pagano, L., Martino, B., D'Antonio, D., Fanci, R., Specchia, G., Mei, L., Buelli, M., Pizzarelli, G., Venditti, M. \& Martino, P. (2005). Invasive infections caused by Trichosporon species and Geotrichum capitatum in patients with hematological malignancies: a retrospective multicenter study from Italy and review of the literature. J. Clin. Microbiol. Vol.43, No.4 (April 2005), pp. 1818-1828, ISSN: 00951137.

Grunwald, S., Pilhofer, M. \& Holl, W. (2010). Microbial associations in gut systems of woodand bark-inhabiting longhorned beetles [Coleoptera: Cerambycidae]. Syst. Appl. Microbiol., Vol.33, No.1 (January 2010), pp. 25-34, ISSN: 0723-2020.

Gujjari, P., Suh, S.O., Lee, C.F. \& Zhou, J.J. (2010). Trichosporon xylopini sp. nov., a hemicellulose-degrading yeast isolated from wood-inhabiting beetle Xylopinus saperdioides. Int J Syst. Evol. Microbiol., IJSEM Papers in Press. Published October 29, 2010 as doi:10.1099/ijs.0.028860-0

Gusmão, D.S., Santos, A.V., Marini, D.C., Russo, E.D., Peixoto, A.M.D., Bacci, M., BerbertMolina, M.A. \& Lemos, F.J.A. (2007). First isolation of microorganisms from the gut diverticulum of Aedes aegypti (Diptera : Culicidae): new perspectives for an insectbacteria association. Mem I Oswaldo Cruz, Vol.102, No.8 (December 2007), pp. 919924, ISSN: 0074-0276.

Gusmão, D.S., Santos, A.V., Marini, D.C., Bacci, M., Berbert-Molina, M.A. \& Lemos, F.J.A. (2010). Culture-dependent and culture-independent characterization of microorganisms associated with Aedes aegypti (Diptera: Culicidae) (L.) and dynamics of bacterial colonization in the midgut. Acta Tropica, Vol.115, No.3 (September 2010), pp. 275-281, ISSN: 0001-706X.

Hansen, L.D. \& Klotz, J.H. (2005). Carpenter ants of the United States and Canada. Cornell University Press, ISBN 0-8014-4262-1, Ithaca, New York.

Hongoh, Y. (2010). Diversity and Genomes of Uncultured Microbial Symbionts in the Termite Gut. Biosci. Biotechnol. Biochem., Vol.74, No.6 (June 2010), pp. 1145-1151, ISSN: 1347-6947.

Hooper, L.V. \& Gordon, J.I. (2001). Commensal host-bacterial relationships in the gut. Science, Vol.292, No.5519 (May 2001), pp. 1115-1118.

Janczyk, P., Pieper, R. \& Souffrant, W.B. (2006) 16 S rDNA polymerase chain reaction denaturing gradient gel electrophoresis used to study the pig intestinal microflora. Abstracts of International Conference "Sustainable Animal Health through Eubiosis - Relevance for Man"., Ascona, Switzerland, 8-13 Oct. 2006 p.16

Jarvis, B. \& Williams, A.P. (1987). Methods for detecting fungi in foods and beverages. In: Food and beverage mycology. L.R. Beuchat (Ed), pp. 599-636 Van Rostrand, ISBN: 0-44221084-1, New York, USA.

Jouany, J.P., Gobert, J., Medina, B., Bertin, G. \& Julliand, V. (2008). Effect of live yeast culture supplementation on apparent digestibility and rate of passage in horses fed a highfiber or high-starch diet. J. Anim Sci., Vol.86, No.2, pp. 339-347.

Jouany, J.P., Medina, B., Bertin, G. \& Julliand, V. (2009). Effect of live yeast culture supplementation on hindgut microbial communities and their polysaccharidase 
and glycoside hydrolase activities in horses fed a high-fiber or high-starch diet. $J$. Anim Sci., Vol.87, No.9 (May 2009), pp. 2844-2852.

King, A.D., Pitt, J.I., Beuchat, L.R. \& Corry, J.E.L. (1986). Methods for the mycological examination of food. Plenum, ISBN-10: 0306424797, New York, USA.

Kostka, V.M., Hoffmann, L., Balks, E., Eskens, U. \& Wimmershof, N. (1997). Review of the literature and investigations on the prevalence and consequences of yeasts in reptiles. Vet. Rec. Vol.140, No.11, pp. 282-287.

Kurtzman, C.P. \& Fell, J.W. (1998). Definition, Classification and Nomenclature of the Yeasts. In: The Yeasts, a Taxonomic Study, 4th ed, Kurtzman, C.P. \& J.W. Fell, (Ed), pp. 3 -5, Elsevier, ISBN: 044481312 8, Amsterdam.

Kurtzman, C.P., Robnett, C.J., Ward, J.M., Brayton, C., Gorelick, P. \& Walsh, T.J. (2005). Multigene phylogenetic analysis of pathogenic candida species in the Kazachstania (Arxiozyma) telluris complex and description of their ascosporic states as Kazachstania bovina sp. nov., K. heterogenica sp. nov., K. pintolopesii sp. nov., and K. slooffiae sp. nov. J. Clin. Microbiol., Vol.43, No.1 (January 2005), pp. 101-111, ISSN: 1098-660X.

Kurtzman, C.P. \& Fell, J.W. (2006). Yeast systematics and phylogeny - implications of molecular identification methods for studies in ecology. In: The Yeast Handbook: Biodiversity and Ecophysiology of Yeasts, Rosa, C.A. \& G. Peter, (Ed), pp. 11-30, Springer-Verlag, ISBN: 978-3-540-26100-1, Berlin Heidelberg.

Lachance, M.A., Starmer, W.T., Rosa, C.A., Bowles, J.M., Barker, J. S. \& Janzen, D.H. (2001). Biogeography of the yeasts of ephemeral flowers and their insects. FEMS Yeast Res, Vol.1, No.1 (April 2001), pp. 1-8, ISSN: 1567-1356.

Lachance, M.A., Daniel, H.M., Meyer, W., Prasad, G.S., Gautam, S. P. \& Boundy-Mills, K. (2003). The D1/D2 domain of the large-subunit rDNA of the yeast species Clavispora lusitaniae is unusually polymorphic. FEMS Yeast Res., Vol.4, No.3 (December 2003), pp. 253-258, ISSN: 1567-1356.

Latgé, J.P. (2007). The cell wall: a carbohydrate armour for the fungal cell. Molecular Microbiology, Vol.66, No.2 (October 2007), pp. 279-290.

Ley, R.E., Hamady, M., Lozupone, C., Turnbaugh, P.J., Ramey, R.R., Bircher, J.S., Schlegel, M.L., Tucker, T.A., Schrenzel, M.D., Knight, R. \& Gordon, J.I. (2008). Evolution of mammals and their gut microbes. Science, Vol.320, No.5883 (June 2008), pp. 16471651.

Lund, A. (1974). Yeasts and Molds in Bovine Rumen. J. Gen. Microbiol., Vol.81, No.2 (April 1974), pp. 453-462, ISSN: 0022-1287.

Lund, A. (1980). Yeasts in the rumen contents of musk oxen. J Gen. Microbiol., Vol.121, No.1, pp. 273-276, ISSN: 0022-1287.

Macnaughton, S.J., Stephen, J.R., Venosa, A.D., Davis, G.A., Chang, Y.J. \& White, D.C. (1999). Microbial population changes during bioremediation of an experimental oil spill. Appl Environ. Microbiol., Vol.65, No.8 (August 1999), pp. 3566-3574, ISSN: 0099-2240.

Mankowski, M.E. \& Morrell, J.J. (2004). Yeasts associated with the infrabuccal pocket and colonies of the carpenter ant Camponotus vicinus. Mycologia, Vol.96, No.2 (March 2004), pp. 226-231, ISSN: 00275514.

Medina, B., Girard, I.D., Jacotot, E. \& Julliand, V. (2002). Effect of a preparation of Saccharomyces cerevisiae on microbial profiles and fermentation patterns in the large 
intestine of horses fed a high fiber or a high starch diet. J. Anim Sci., Vol.80, No.10, (October 2002), pp. 2600-2609, ISSN: 00218812.

Mehnert, B. \& Koch, U. (1963). Über das Vorkommen von im Verdauungstrakt des Schweines vermehrungsfähiger Hefen. Zbl. Bakter. I. Orig., Vol.188, pp. 103-120.

Molnar, O., Schatzmayr, G., Fuchs, E. \& Prillinger, H. (2004). Trichosporon mycotoxinivorans sp nov., a new yeast species useful in biological detoxification of various mycotoxins. Syst. Appl. Microbiol., Vol.27, No.6 (December 2004), pp. 661-671, ISSN: 0723-2020.

Molnar, O. \& Prillinger, H. (2005). Analysis of yeast isolates related to Metschnikowia pukherrima using the partial sequences of the large subunit rDNA and the actin gene; description of Metschnikowia andauensis sp nov. Syst. Appl. Microbiol., Vol.28, No.8 (October 2005), pp. 717-726, ISSN: 0723-2020.

Molnar, O., Wuczkowski, M. \& Prillinger, H. (2008). Yeast biodiversity in the guts of several pests on maize; comparison of three methods: classical isolation, cloning and DGGE. Mycol. Prog., Vol.7, No.2 (April 2008 in SpringerLink), pp. 111-123, ISSN: 1861-8952.

Nagahama, T. (2006). Yeast Biodiversity in Freshwater, Marine and Deep-Sea Environments. In: The Yeast Handbook: Biodiversity and Ecophysiology of Yeasts, C.A. Rosa \& G. Peter (Ed), pp. 241-262, Springer-Verlag, ISBN: 978-3-540-26100-1, Berlin Heidelberg.

Nguyen, N.H., Suh, S.O., Erbil, C.K. \& Blackwell, M. (2006). Metschnikowia noctiluminum sp. nov., Metschnikowia corniflorae sp. nov., and Candida chrysomelidarum sp. nov., isolated from green lacewings and beetles. Mycol. Res, Vol.110, No.Pt3 (March 2006), pp. 346-356, ISSN: 0953-7562.

Nguyen, N.H., Suh, S.O. \& Blackwell, M. (2007). Five novel Candida species in insectassociated yeast clades isolated from Neuroptera and other insects. Mycologia, Vol.99, No.6, pp. 842-858.

Odds, F.C. (1991). Sabouraud('s) agar. J Med Vet. Mycol, Vol.29, No.6, pp. 355-359.

Pagnocca, F.C., Legaspe, M.F., Rodrigues, A., Ruivo, C.C., Nagamoto, N.S., Bacci, M.Jr. \& Forti, L.C. (2010). Yeasts isolated from a fungus-growing ant nest, including the description of Trichosporon chiarellii sp. nov., an anamorphic basidiomycetous yeast. Int J Syst. Evol. Microbiol., Vol.60, No.Pt6 (June 2010), pp. 1454-1459.

Parle, J.N. (1957). Yeasts Isolated from the Mammalian Alimentary Tract. J. Gen. Microbiol., Vol.17, No.2 (October 1957 ), pp. 363-367, ISSN: 0022-1287.

Pérez Gutiérrez, O. (2010). Unraveling Piglet Gut Microbiota Dynamics in Response to Feed Additives microbiota. PhD Thesis, Wageningen University, Wageningen, The Netherlands, ISBN 978-90-8585-684-9.

Phaff, H.J. \& Starmer, W.T. (1987). Yeasts associated with plants, insects and soil. In: The yeasts, A.H. Rose \& J. S. Hartison (Ed), pp. 123-180. Academic Press Inc., ISBN 0-12596411-0, London.

Prakitchaiwattana, C.J., Fleet, G.H. \& Heard, G.M. (2004). Application and evaluation of denaturing gradient gel electrophoresis to analyse the yeast ecology of wine grapes. FEMS Yeast Res., Vol.4, No.8 (September 2004), pp. 865-877, ISSN: 1567-1356.

Prillinger, H., Messner, R., Konig, H., Bauer, R., Lopandic, K., Molnar, O., Dangel, P., Weigang, F., Kirisits, T., Nakase, T. \& Sigler, L. (1996). Yeasts associated with termites: A phenotypic and genotypic characterization and use of coevolution for 
dating evolutionary radiations in asco- and basidiomycetes. Syst. Appl. Microbiol., Vol.19, No.2, pp. 265-283, ISSN: 0723-2020.

Rao, R.S., Bhadra, B. \& Shivaji, S. (2007). Isolation and characterization of xylitol-producing yeasts from the gut of colleopteran insects. Curr. Microbiol., Vol.55, No.5 (August 21, 2007 ), pp. 441-446, ISSN: 0343-8651.

Ricci, I., Damiani, C., Scuppa, P., Mosca, M., Crotti, E., Rossi, P., Rizzi, A., Capone, A., Gonella, E., Ballarini, P., Chouaia, B., Sagnon, N.F., Esposito, F., Alma, A., Mandrioli, M., Sacchi, L., Bandi, C., Daffonchio, D. \& Favia, G. (2011a). The yeast Wickerhamomyces anomalus (Pichia anomala) inhabits the midgut and reproductive system of the Asian malaria vector Anopheles stephensi. Environ. Microbiol., Vol.13, No.4 (April 2011), pp. 911-921, ISSN: 1462-2912

Ricci, I., Mosca, M., Valzano, M., Damiani, C., Scuppa, P., Rossi, P., Crotti, E., Cappelli, A., Ulissi, U., Capone, A., Esposito, F., Alma, A., Mandrioli, M., Sacchi, L., Bandi, C., Daffonchio, D. \& Favia, G. (2011b). Different mosquito species host Wickerhamomyces anomalus (Pichia anomala): perspectives on vector-borne diseases symbiotic control. Anton. Leeuw. Int. J. G., Vol.99, No.1 (Januar 2011), pp. 43-50, ISSN: 0003-6072.

Rivera, F.N., Gonzalez, E., Gomez, Z., Lopez, N., Hernandez-Rodriguez, C., Berkov, A. \& Zuniga, G. (2009). Gut-associated yeast in bark beetles of the genus Dendroctonus Erichson (Coleoptera: Curculionidae: Scolytinae). Biol. J. Linn. Soc., Vol.98, No.2 (October 2009), pp. 325-342, ISSN: 0024-4066.

Rodrigues, A., Cable, R.N., Mueller, U.G., Bacci, M.Jr. \& Pagnocca, F.C. (2009). Antagonistic interactions between garden yeasts and microfungal garden pathogens of leafcutting ants. Antonie Van Leeuwenhoek, Vol.96, No.3 (May 2009 in SpringerLink), pp. 331-342, ISSN: 0003-6072.

Rosa, C.A. \& Peter, G. (2006). The Yeast Handbook: Biodiversity and Ecophysiology of Yeasts. Germany: Springer-Verlag, ISBN-10: 3-540-26100-1, Berlin Heidelberg.

Schäfer, A., Konrad, R., Kuhnigk, T., Kampfer, P., Hertel, H. \& Konig, H. (1996). Hemicellulose-degrading bacteria and yeasts from the termite gut. J Appl. Bacteriol., Vol.80, No.5 (May 1996), pp. 471-478, ISSN: 0021-8847.

Schulze, J. \& Sonnenborn, U. (2009). Yeasts in the gut: from commensals to infectious agents. Dtsch. Arztebl. Int., Vol.106, No.51-52 (December 2009), pp. 837-842, ISSN: 18660452 .

Scorzetti, G., Fell, J.W., Fonseca, A. \& Statzell-Tallman, A. (2002). Systematics of basidiomycetous yeasts: a comparison of large subunit D1/D2 and internal transcribed spacer rDNA regions. FEMS Yeast Res., Vol.2, No.4 (December 2002), pp. 495-517, ISSN: 1567-1356.

Scupham, A.J., Presley, L.L., Wei, B., Bent, E., Griffith, N., McPherson, M., Zhu, F., Oluwadara, O., Rao, N., Braun, J. \& Borneman, J. (2006). Abundant and diverse fungal microbiota in the murine intestine. Appl. Environ. Microbiol., Vol.72, No.1 (January 2006), pp. 793-801, ISSN: 0099-2240.

Shifrine, M. \& Phaff, H. J. (1956). The Association of Yeasts with Certain Bark Beetles. Mycologia, Vol.48, No. 1, (January- February 1956), pp. 41-55, ISSN: 00275514.

Shin, E.C., Kim, Y.K., Lim, W.J., Hong, S.Y., An, C.L., Kim, E.J., Cho, K.M., Choi, B.R., An, J.M., Kang, J.M., Jeong, Y.J., Kwon, E.J., Kim, H. \& Yun, H. D. (2004). Phylogenetic 
analysis of yeast in the rumen contents of cattle based on the 26S rDNA sequence. $J$ Agric Sci, Vol.142, No.05 (March 2005), pp. 603-611, ISSN: 00218596.

Suh, S.O., Marshall, C.J., Mchugh, J. V. \& Blackwell, M. (2003). Wood ingestion by passalid beetles in the presence of xylose-fermenting gut yeasts. Mol. Ecol., Vol.12, No.11 (November 2003) , pp. 3137-3145, ISSN: 0962-1083.

Suh, S.O. \& Blackwell, M. (2004). Three new beetle-associated yeast species in the Pichia guilliermondii clade. FEMS Yeast Res, Vol.5, No.1 (October 2004), pp. 87-95, ISSN: 1567-1356.

Suh, S.O., Gibson, C.M. \& Blackwell, M. (2004a). Metschnikowia chrysoperlae sp. nov., Candida picachoensis sp. nov. and Candida pimensis sp. nov., isolated from the green lacewings Chrysoperla comanche and Chrysoperla carnea (Neuroptera: Chrysopidae). Int J Syst. Evol. Microbiol., Vol.54, No.Pt5 (September 2004), pp. 1883-1890, ISSN: 1466-5026.

Suh, S.O., Mchugh, J.V. \& Blackwell, M. (2004b). Expansion of the Candida tanzawaensis yeast clade: 16 novel Candida species from basidiocarp-feeding beetles. Int J Syst. Evol. Microbiol., Vol.54, No.Pt6 (November 2004), pp. 2409-2429, ISSN: 1466-5026.

Suh, S.O. \& Blackwell, M. (2005). Four new yeasts in the Candida mesenterica clade associated with basidiocarp-feeding beetles. Mycologia, Vol.97, No.1 (January- February 2005), pp. 167-177, ISSN: 0027-5514.

Suh, S.O., Mchugh, J.V., Pollock, D.D. \& Blackwell, M. (2005a). The beetle gut: a hyperdiverse source of novel yeasts. Mycol. Res., Vol.109, No.Pt3 (March 2005), pp. 261-265, ISSN: 0953-7562.

Suh, S.O., Nguyen, N.H. \& Blackwell, M. (2005b). Nine new Candida species near C. membranifaciens isolated from insects. Mycol. Res, Vol.109, No.Pt9 (September 2005), pp. 1045-1056, ISSN: 0027-5514.

Suh, S.O. \& Blackwell, M. (2006). Three new asexual arthroconidial yeasts, Geotrichum carabidarum sp. nov., Geotrichum histeridarum sp. nov., and Geotrichum cucujoidarum sp. nov., isolated from the gut of insects. Mycol. Res, Vol.110, No.Pt2 (Februar 2006), pp. 220-228, ISSN: 0953-7562.

Suh, S.O., Blackwell, M., Kurtzman, C.P. \& Lachance, M.A. (2006a). Phylogenetics of Saccharomycetales, the ascomycete yeasts. Mycologia, Vol.98, No.6 (NovemberDecember 2006), pp. 1006-1017, ISSN: 0027-5514.

Suh, S.O., Nguyen, N.H. \& Blackwell, M. (2006b). A yeast clade near Candida kruisii uncovered: nine novel Candida species associated with basidioma-feeding beetles. Mycol. Res Vol.110, No.Pt2 (December 2006), pp. 1379-1394, ISSN: 0953-7562.

Suh, S.O., Nguyen, N.H. \& Blackwell, M. (2008). Yeasts isolated from plant-associated beetles and other insects: seven novel Candida species near Candida albicans. FEMS Yeast Res., Vol.8, No.1 (Februar 2008), pp. 88-102, ISSN: 1567-1356.

Tiedje, J.M., Asuming-Brempong, S., Nüsslein, K., Marsh, T.L. \& Flynn, S.J. (1999). Opening the black box of soil microbial diversity. Appl. Soil Ecol., Vol.13, No.2 (October 1999), pp. 109-122, ISSN: 0929-1393.

Travassos, L.R.R.G. \& Cury, A. (1971). Thermophilic Enteric Yeasts. Annu. Rev. Microbiol., Vol.25, No.1 (October 1971), pp. 49-74, ISSN: 0066-4227.

Urubschurov, V., Janczyk, P., Pieper, R. \& Souffrant, W.B. (2008). Biological diversity of yeasts in the gastrointestinal tract of weaned piglets kept under different farm 
conditions. FEMS Yeast Res., Vol.8, No.8 (December 2008), pp. 1349-1356, ISSN: 1567-1356.

Urubschurov, V., Janczyk, P., Souffrant, W.B., Freyer, G. \& Zeyner, A. (2011). Establishment of intestinal microbiota with focus on yeasts of unweaned and weaned piglets kept under different farm conditions. FEMS Microbiol.Ecol., in Press

Van Uden, N. \& do. Carmo-Sousa, L. (1957a). Candida slooffii nov.sp., a thermophilic and vitamin deficient yeast from the equine intestinal tract. Portug. Acta Biol, Vol.V, pp. 7-17, ISSN 0874-9035.

Van Uden, N. \& do. Carmo-Sousa, L. (1957b). Yeasts from the bovine caecum. J. Gen. Microbiol., Vol.16, No.2 (April 1957), pp. 385-395, ISSN: 1350-0872.

Van Uden, N. \& do. Carmo-Sousa, L. (1962). Quantitative aspects of the intestinal yeast flora of swine. J. Gen. Microbiol., Vol.27, No.1 (January 1962), pp. 35-40, ISSN: 1350-0872.

Van Uden, N., do. Carmo-Sousa, L., \& Farinha, M. (1958). On the intestinal yeast flora of horses, sheep, goats and swine. J. Gen. Microbiol., Vol.19, No.3 (December 1958), pp. 435-445, ISSN: 1350-0872.

Woolfolk, S.W., Cohen, A.C. \& Inglis, G.D. (2004). Morphology of the alimentary canal of Chrysoperla rufilabris (Neuroptera : Chrysopidae) adults in relation to microbial symbionts. Ann Entomol Soc Am Vol.97, No.4, pp. 796-808, ISSN: 0013-8746.

Woolfolk, S.W. \& Inglis, G.D. (2004). Microorganisms associated with field-collected Chrysoperla rufilabris (Neuroptera: Chrysopidae) adults with emphasis on yeast symbionts. Biol Control, Vol.29, No.2 (February 2004), pp. 155-168, ISSN: 1049-9644.

Yarrow, D. \& Meyer, S.A. (1978). Proposal for Amendment of Diagnosis of Genus Candida Berkhout Nom Cons. Int. J. Syst. Bacteriol., Vol.28, No.4, pp. 611-615, ISSN: 14665026 . 


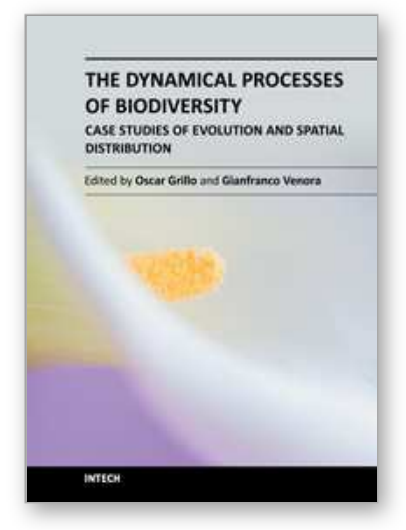

\author{
The Dynamical Processes of Biodiversity - Case Studies of \\ Evolution and Spatial Distribution \\ Edited by PhD. Oscar Grillo
}

ISBN 978-953-307-772-7

Hard cover, 366 pages

Publisher InTech

Published online 02, December, 2011

Published in print edition December, 2011

Driven by the increasing necessity to define the biological diversity frame of widespread, endemic and threatened species, as well as by the stimulating chance to describe new species, the study of the evolutive and spatial dynamics is in constant execution. Systematic overviews, biogeographic and phylogenic backgrounds, species composition and distribution in restricted areas are focal topics of the 15 interesting independent chapters collected in this book, chosen to offer to the reader an overall view of the present condition in which our planet is.

\title{
How to reference
}

In order to correctly reference this scholarly work, feel free to copy and paste the following:

Vladimir Urubschurov and Pawel Janczyk (2011). Biodiversity of Yeasts in the Gastrointestinal Ecosystem with Emphasis on Its Importance for the Host, The Dynamical Processes of Biodiversity - Case Studies of Evolution and Spatial Distribution, PhD. Oscar Grillo (Ed.), ISBN: 978-953-307-772-7, InTech, Available from:

http://www.intechopen.com/books/the-dynamical-processes-of-biodiversity-case-studies-of-evolution-andspatial-distribution/biodiversity-of-yeasts-in-the-gastrointestinal-ecosystem-with-emphasis-on-its-importancefor-the-hos

\section{INTECH}

open science | open minds

\section{InTech Europe}

University Campus STeP Ri Slavka Krautzeka 83/A 51000 Rijeka, Croatia Phone: +385 (51) 770447 Fax: +385 (51) 686166 www.intechopen.com

\section{InTech China}

Unit 405, Office Block, Hotel Equatorial Shanghai

No.65, Yan An Road (West), Shanghai, 200040, China 中国上海市延安西路65号上海国际贵都大饭店办公楼 405 单元

Phone: +86-21-62489820

Fax: +86-21-62489821 
(C) 2011 The Author(s). Licensee IntechOpen. This is an open access article distributed under the terms of the Creative Commons Attribution 3.0 License, which permits unrestricted use, distribution, and reproduction in any medium, provided the original work is properly cited. 